Delft University of Technology

\title{
Eleven years of mangrove-mudflat dynamics on the mud volcano-induced prograding delta in east java, indonesia \\ Integrating uav and satellite imagery
}

Beselly, Sebrian Mirdeklis; van der Wegen, Mick; Grueters, Uwe; Reyns, Johan; Dijkstra, Jasper; Roelvink, Dano

DOI

10.3390/rs13061084

Publication date

2021

Document Version

Final published version

Published in

Remote Sensing

\section{Citation (APA)}

Beselly, S. M., van der Wegen, M., Grueters, U., Reyns, J., Dijkstra, J., \& Roelvink, D. (2021). Eleven years of mangrove-mudflat dynamics on the mud volcano-induced prograding delta in east java, indonesia: Integrating uav and satellite imagery. Remote Sensing, 13(6), 1-28. [1084].

https://doi.org/10.3390/rs13061084

Important note

To cite this publication, please use the final published version (if applicable).

Please check the document version above.

\section{Copyright}

Other than for strictly personal use, it is not permitted to download, forward or distribute the text or part of it, without the consent of the author(s) and/or copyright holder(s), unless the work is under an open content license such as Creative Commons.

\section{Takedown policy}

Please contact us and provide details if you believe this document breaches copyrights.

We will remove access to the work immediately and investigate your claim. 


\title{
Eleven Years of Mangrove-Mudflat Dynamics on the Mud Volcano-Induced Prograding Delta in East Java, Indonesia: Integrating UAV and Satellite Imagery
}

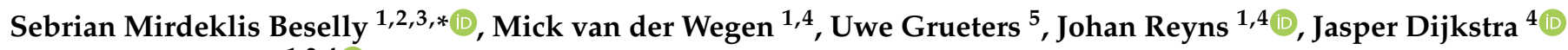 \\ and Dano Roelvink 1,2,4 (iD \\ 1 Department of Coastal \& Urban Risk \& Resilience, Coastal Systems \& Engineering and Port Development, \\ IHE Delft Institute for Water Education, Westvest 7, 2611 AX Delft, The Netherlands; \\ m.vanderwegen@un-ihe.org (M.v.d.W.); j.reyns@un-ihe.org (J.R.); d.roelvink@un-ihe.org (D.R.) \\ 2 Department of Hydraulic Engineering, Section Coastal Engineering, Delft University of Technology, \\ Stevinweg 1, 2628 CN Delft, The Netherlands \\ 3 Department of Water Resources Engineering, Brawijaya University, Malang 65145, Indonesia \\ 4 Deltares, 2629 HV Delft, The Netherlands; jasper.dijkstra@deltares.nl \\ 5 Institute of Plant Ecology, Justus Liebig University, 35392 Giessen, Germany; \\ uwe.grueters@bot2.bio.uni-giessen.de \\ * Correspondence: s.m.beselly@tudelft.nl; Tel.: +31-152-151-160
}

Citation: Beselly, S.M.; van der Wegen, M.; Grueters, U.; Reyns, J.; Dijkstra, J.; Roelvink, D. Eleven Years of Mangrove-Mudflat Dynamics on the Mud Volcano-Induced Prograding Delta in East Java, Indonesia: Integrating UAV and Satellite Imagery. Remote Sens. 2021, 13, 1084. https://doi.org/10.3390/rs13061084

Academic Editors:

Farid Dahdouh-Guebas and Viviana Otero

Received: 27 January 2021

Accepted: 10 March 2021

Published: 12 March 2021

Publisher's Note: MDPI stays neutral with regard to jurisdictional claims in published maps and institutional affiliations.

Copyright: (c) 2021 by the authors. Licensee MDPI, Basel, Switzerland. This article is an open access article distributed under the terms and conditions of the Creative Commons Attribution (CC BY) license (https:// creativecommons.org/licenses/by/ $4.0 /)$.
Abstract: This article presents a novel approach to explore mangrove dynamics on a prograding delta by integrating unmanned aerial vehicle (UAV) and satellite imagery. The Porong Delta in Indonesia has a unique geographical setting with rapid delta development and expansion of the mangrove belt. This is due to an unprecedented mud load from the LUSI mud volcanic eruption. The mangrove dynamics analysis combines UAV-based Structure from Motion (SfM) photogrammetry and 11 years (2009-2019) satellite imagery cloud computing analysis by Google Earth Engine (GEE). Our analysis shows unique, high-spatiotemporal-resolution mangrove extent maps. The SfM photogrammetry analysis leads to a 3D representation of the mangrove canopy and an estimate of mangrove biophysical properties with accurate height and individual position of the mangroves stand. GEE derived vegetation indices resulted in high (three-monthly) resolution mangrove coverage dynamics over 11 years (2009-2019), yielding a value of more than 98\% for the overall, producer and consumer accuracy. Combining the satellite-derived age maps and the UAV-derived spatial tree structure allowed us to monitor the mangrove dynamics on a rapidly prograding delta along with its structural attributes. This analysis is of essential value to ecologists, coastal managers, and policymakers.

Keywords: mangroves; remote sensing; Google Earth Engine; SfM photogrammetry; UAV

\section{Introduction}

Mangroves are trees or large shrubs that grow in or adjacent to the intertidal zone and are distributed along (sub-)tropical coasts and estuaries [1,2]. Mangroves are well-known for providing a range of ecosystem services such as timber production, carbon sequestration, soil formation, nutrient cycling, habitat creation for marine and terrestrial species, and protecting coastlines by attenuating waves and limiting erosion [2-4]. However, land use conversion has caused mangrove forests to decline at a rate three to five times larger than the average forest loss. Hence, mangroves' important ecosystem services will be diminished [2].

In order to gain a better understanding of the value of important ecological services provided by mangroves, further efficient collection of data, e.g., mangrove extent, height, individual position, and species membership are necessary. Earth observation offers a method for the large-scale monitoring and assessment of the environment, especially when it comes to the mangrove forest inventory and spatial extent monitoring that are generally 
difficult to carry out on the ground [5]. Mapping mangrove forests is one of the most challenging tasks in remote sensing since the forests are mostly quite large, located in a remote area, and persistent cloud cover in the tropical areas [2,6,7]. Several efforts have been made to monitor the spatial extent of mangrove forests from local to the global scales. Two global-scale mangrove extent maps were released for 2000, i.e., the World Atlas of Mangrove (WAM) [1] and the Global Mangrove Forest Distribution v1 (GMFD) [8]. Other current global products are the Continuous Global Mangrove Forest Cover for the 21st Century (GCMFC-21) that showing annual global mangrove forest cover from 2000 to 2012 [9] and Global Mangrove Watch (GMW) v2.0 [10].

Information on important structural attributes of mangroves such as tree height, age, and diameter at breast height $(\mathrm{dbh})$ is required to characterise the mangrove forest stands. Accurate information of tree height is essential, since there is a high correlation of the height and the dbh, basal area (BA), and above ground biomass (AGB) [5,11]. Mangrove forests with their harsh physical conditions hinder surveyors from carrying out direct measurements in the field. In principle, a number of remote sensing approaches have been developed as supplement or substitute for ground-based inventory [12-15]. A Canopy Height Model (CHM) - that is, a three-dimensional representation of the forest—can be derived by using airborne or terrestrial LiDAR, Synthetic Aperture Radar (SAR), and high-resolution optical imagery [16].

Global satellite datasets such as Shuttle Radar Topography Mission (SRTM) and ICESat/ GLAS [16,17], and ICESat-2/ATLAS launched in 2018 [18] have proven to be useful in deriving canopy height, but they were released in a medium resolution of $30 \mathrm{~m} \times 30 \mathrm{~m}$. TanDEM-X InSAR, a DEM product developed by the German Space Agency (2011-2015) with a ground resolution of $12.5 \times 12.5 \mathrm{~m}$, has also been used to estimate canopy height [14]. Recently, Very High Resolution (VHR) CHM derived from Unmanned Aerial Vehicle (UAV)based Structure from Motion (SfM) Photogrammetry has been deployed $[15,16]$ often at a local scale. The SRTM, ICESat, and TanDEM are the most commonly utilised methods to estimate CHM since they have global coverage, and the data are easily accessible [19]. However, the passive/optical sensors solely obtain surface canopy information, and radar has at least limited penetration capability [19]. LiDAR, on the other hand, is able to penetrate the canopy cover to some extent depending on the acquisition design and lidar system [20]. However, this technique can be associated with high cost which limits the use of this system [16,19].

This study takes the Porong Estuary, Indonesia, as a case study. Porong Estuary provided a unique setting as this area is characterised by a rapidly prograding delta and concomitant mangrove expansion [21-23]. It is because of the mud volcanic eruption in 2006 and subsequent mudflow diversion known as LUSI (acronym of lumpur (mud) and sidoarjo (the regency name)) [23]. Several studies have been conducted to investigate the effects of LUSI's high sediment load on the Porong River, the Porong Estuary, and surrounding coastal waters $[21,24,25]$ and the development of mangrove on the created wetland in general [26-28]. However, none of them explored the mangrove dynamics and investigated the structural characterisation of the mangroves in the rapidly prograding delta.

This study aims to analyse mangrove dynamics on a rapidly prograding delta by a novel integration of UAV SfM Photogrammetry and multiple sources of satellite imagery in cloud computing Google Earth Engine (GEE). The first objective of this study is to retrieve mangrove biophysical properties (height and individual location of trees) employing the off-the-shelf UAV SfM photogrammetry, in combination with ground-truthing based on field data. The second objective is to generate a three-monthly classification of mangrove areas using Landsat 7, Landsat 8, Sentinel 1, and Sentinel 2 in GEE. These mangrove extent maps represent the dry season and wet season, where two maps were created during each of these seasons every three months. The third objective is to estimate the mangrove age and age-height relationship based on the combination of UAV and GEE analysis. 


\section{Materials and Methods}

\subsection{Study Area}

The Porong Delta, as presented in Figure 1 is located in East Java Province, Indonesia (7.569 S, $112.872 \mathrm{E})$. It is approximately $37 \mathrm{~km}$ southeast of Surabaya, the second-largest city in Indonesia. It has a monsoon climate with a dry (April-September) and wet (OctoberMarch) season [29], in which the high precipitation contributes up to $80 \%$ of the mean annual precipitation [30]. The Porong River is one of the two major branches of the Brantas watershed. The watershed is regulated with several large dams, barrages, and flood gates. During the dry season, the flow is diverted to Surabaya, and therefore the flow in the Porong River is often reduced to almost zero [31]. During the wet season flood discharge is diverted from the upstream barrage and high precipitation contributes to high river flow that discharges into the Madura Strait [24,25]. Madura Strait has a micro to the meso-tidal range and is categorised by a mixed diurnal-semidiurnal tide [32].
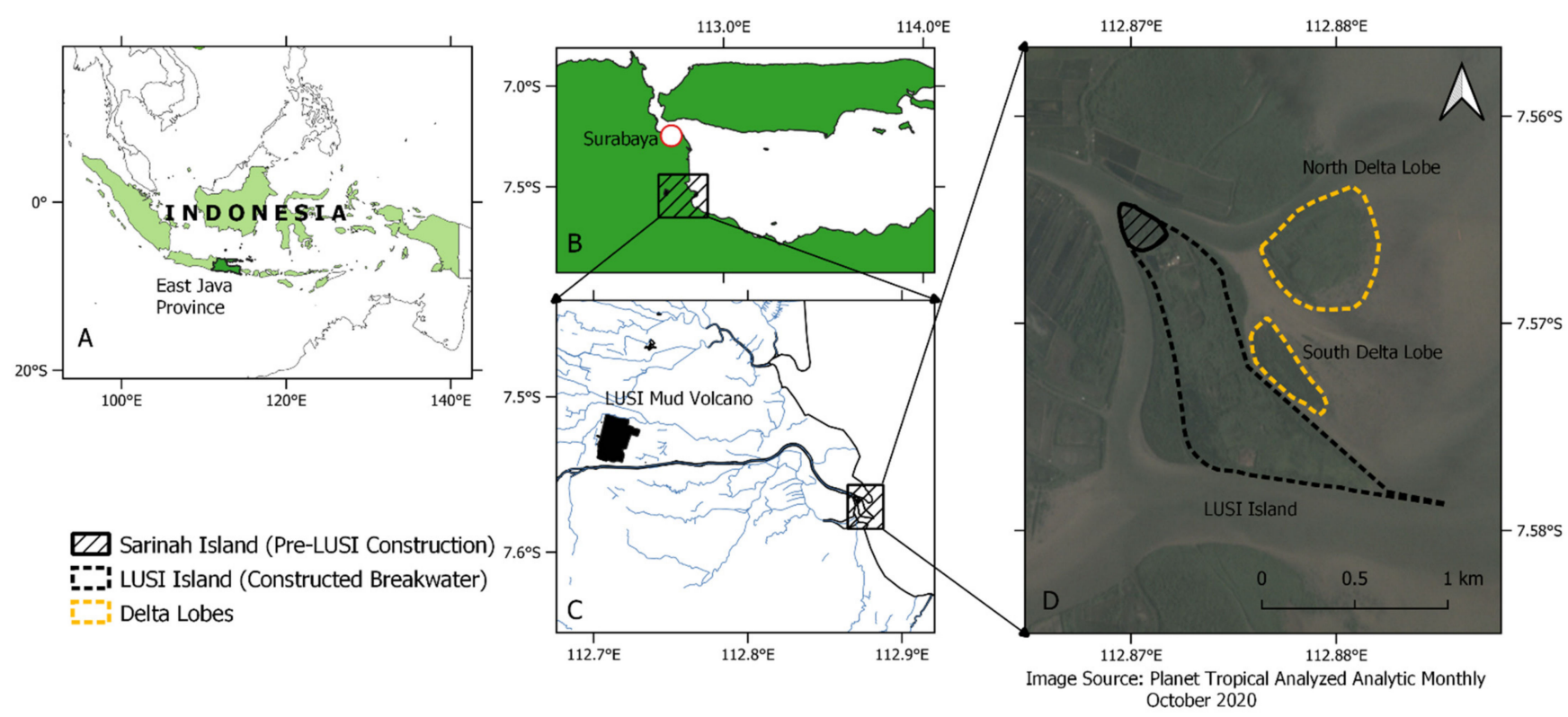

Figure 1. The study area is described in a sequence: (A) Indonesian border (light green) with East Java Province depicted in dark green, (B) East Java Province and the capital city Surabaya (represented as a red circle), (C) LUSI (lumpur (mud) and sidoarjo (the regency name)) mud volcano represented as a black polygon, and the Porong River as the black line flowing from the west to the east part of the map, and (D) Porong Estuary with LUSI island and the delta lobes.

The Brantas river originates from the volcanic complex of the Semeru and Arjuno Mountains [32]. Erosion rates on the slopes of Mount Semeru are among the highest recorded in the world (105-106 $\mathrm{m}^{3} \mathrm{~km}^{-2} \mathrm{a}^{-1}$ ) [33]. Sediment yield in several drainage basins of Mount Semeru is dominated by rain-triggered events during the wet season [30,33]. The Brantas watershed is densely populated and affected by anthropogenic activities such as deforestation, intensive agriculture (mainly rice cultivation), and industries [34]. Due to the geological conditions consisting of the presence of easily erodible soils and high anthropogenic activities, surface erosion is high [31]. The Porong River drains off high sediment loads, causing a prograding delta [34,35] with a progradation rates of approximately $0.4 \times 10^{6} \mathrm{~m}^{2} \mathrm{y}^{-1}$ over the 1935-1981 period [21,31].

In addition to the sediment load due to runoff from the hinterland, the Porong River has been experiencing an extreme sediment load due to the mud volcanic eruption in Sidoarjo, Indonesia. The LUSI mudflow is reported to be the 'largest mud eruption in the world' [36], about $18 \mathrm{~km}$ west of Porong Delta (Figure 1). On 29 May 2006, the boiling mud erupted at a peak flow rate of up to $180,000 \mathrm{~m}^{3}$ day ${ }^{-1}$ [22] which declined to $50,000 \mathrm{~m}^{3} \mathrm{~d}^{-1}$ in September 2011 [23]. Sixty thousand residents were forced to evacuate, and $7 \mathrm{~km}^{2}$ of residential area was submerged with mud [36] (Figure 2a). The excessive LUSI is still 
actively erupting material, gas, water, clasts, and oil, albeit at a considerably reduced rate [36]. The continuous discharge of mud has been diverted to the Porong River since 2007 [23]. To reduce damage to the nearby community and environment, the mud in LUSI is first stored in a reservoir contained by 10-m-tall dyke and then diluted and disposed of by pumping to the river [21,36]. This operation has increased sediment concentration and loads of the Porong River by a factor of 3-4 compared to pre-LUSI conditions [21,23,34]. As shown in Figure $2 b$, due to the mudflow, the delta is rapidly prograding along with the development of mangrove belts. To date, the LUSI mud volcano is still erupting with no end in sight [36].
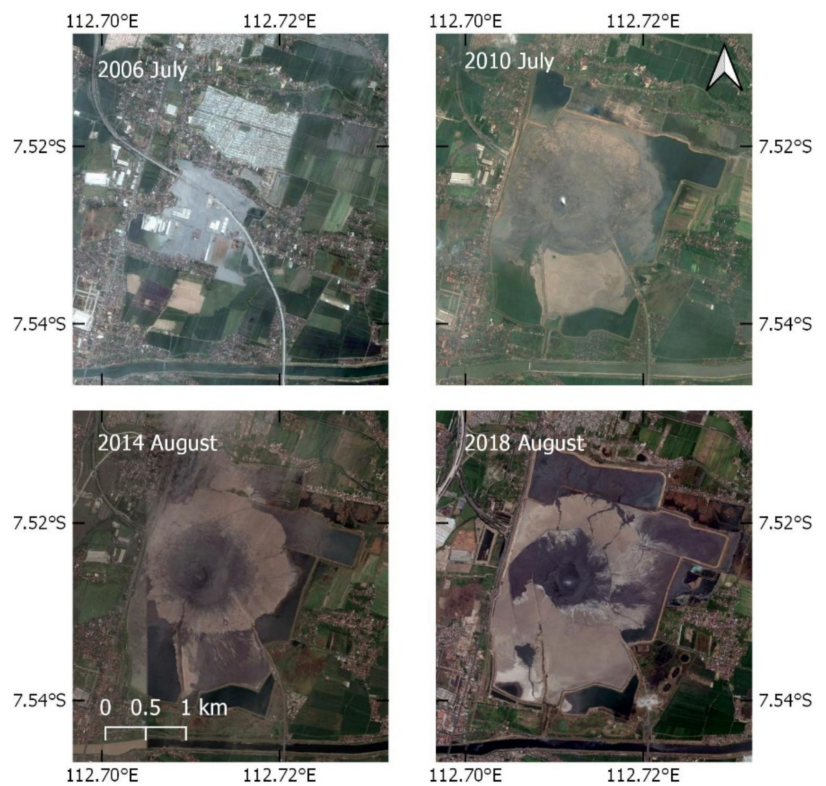

(a)
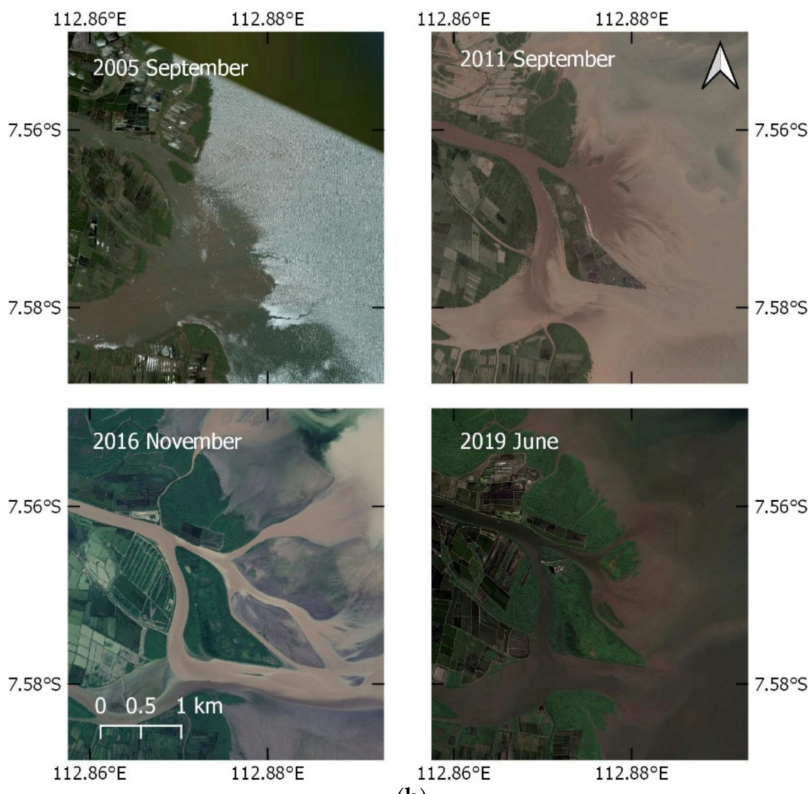

(b)

Figure 2. (a) Series of images of LUSI mud volcano eruption that show the expansion of the inundated area due to the mud volcanic eruption and the ring dyke to contain the mud and (b) Porong Delta development after diversion operation which shows rapid delta and mangrove belt expansion. Source: Google Earth Pro.

The delta lobes (Figure 1) have naturally developed, while LUSI Island was created as a spoil bank to contain sediment dredged from Porong River, after severe siltation due 
to the mud diversion operations. It was constructed between February and November 2009 by building a $4 \mathrm{~km}$ series of geotube breakwaters which were attached to the natural existing Sarinah Island [23]. In 2009, 5000 Avicennia spp. seedlings were planted at this newly created wetland [23,37], and the Ministry of Marine Affairs and Fisheries continued planting thousands of Rhizophora spp. seedlings between 2010 and 2011 [26,27].

\subsection{UAV Data Collection and Processing}

The fieldwork was conducted at the end of the dry season (October-November) in 2019, focusing on two delta lobes (northern and southern deltas) with a total area of approximately $0.3 \mathrm{~km}^{2}$. This timeframe was expected to have a higher probability of clear satellite images with limited cloud cover, and more sunlight as well as less shadows to reach an optimum condition for unmanned aerial vehicle (UAV) image acquisition. UAV/ drones are widely accepted as standard survey tools in many environment settings [38], generating high-resolution data in a safe, straightforward, and cost-effective way [39]. Coastal environments are challenging for the UAV-based surveying method because of the low texture and contrast of the bed surface [39]. Careful planning of the GCPs placement and flight path can lead to reach centimetres of vertical accuracy $[15,39]$.

\subsubsection{Data Acquisition}

Several studies demonstrated that consumer-grade UAV could achieve vertical accuracies in the order of a few centimetres to a few decimetres in coastal topographical surveying [38-40]. In comparison with other low-cost platforms (e.g., kite, pole, and fixedwing), a consumer (rotary) drone system with its integrated positioning system, inertial measurement unit, and stabilised camera offers flexibility and efficiency while attaining the accuracy in coastal area application $[39,41,42]$.

In this study, we used consumer-grade UAV DJI Mavic Pro (DJI, Shenzen, China) during the field campaign. The drone has four propellers and a built-in true colour camera. The camera is equipped with $1 / 2.3^{\prime \prime}$ CMOS sensor with total effective pixels of $12.35 \mathrm{M}$, which produces a $4000 \times 3000$ image resolution and equipped with an electronic shutter. Information on shutter type is important since it will affect the setting on the camera calibration to compensate the rolling shutter issues as in the electronic shutter-type cameras. The overall flight time in optimal condition is $21 \mathrm{~min}$ with $15 \%$ remaining battery level [43].

The DroneDeploy web app (DroneDeploy, San Fransisco, CA, USA) was used to define the flight path [40]. It was planned with a flight altitude of $60 \mathrm{~m}$, an overlay of $80 \%$ front overlap and $75 \%$ side overlap. Each flight was designed to cover $0.02 \mathrm{~km}^{2}$ area with 15 min flight time to limit one battery per flight. An enhanced 3D mode was activated to improve 3D structures quality which will capture an oblique image of the objects, facing toward the inner centre of the target by carefully not to include horizon in the shots [44]. We added a buffer zone approximately $20 \mathrm{~m}$ apart from the edge of the low tide limit that was cropped during the processing later on to prevent interference with the SfM Photogrammetry processing [15]. With these settings, we were able to build 15 grids covering around $0.3 \mathrm{~km}^{2}$. All the grids created in the web app then can be synced into the mobile app to manage the flight and photo acquisition on-field automatically. The flights were conducted between 09:00 and 12:00 to get optimum natural sunlight, primarily limit the appearance of shadows on the photos. Additionally, this short time window was chosen to avoid high variation in sun intensity [45] and it covered the low-tide period. Before the flight, we placed the custom made printed red cross-shape tarpaulin as a ground control point (GCP). The GCP size is $1 \mathrm{~m} \times 1 \mathrm{~m}$ rectangle in the inner side and $1 \mathrm{~m}$ diagonal cross in the outer side to make it identifiable from the $60 \mathrm{~m}$ altitude. We placed GCPs over the mudflat and in the middle of the delta, which has low vegetation density and registered them with DGPS in RTK mode.

In total, the properties and location of 69 mangrove trees were measured concurrently with the mudflat topography. We recorded diameter at breast height (dbh), height, and 
location for each tree. The dbh was recorded using a measuring tape at $130 \mathrm{~cm}$ above the ground. Tree height was recorded with laser rangefinder by measuring horizontal distance and hypotenuse from surveyor location to the tree stem and treetop, respectively. For the trees that were located in the proximity of the mangrove edge we recorded the position with DGPS. Trees that were located more in the centre of the forest were recorded with GPS (horizontal accuracy $\pm 3.5 \mathrm{~m}$ ) because it is difficult to walk inside the forest with heavy equipment. Mudflat topography was measured with DGPS in RTK mode. The mangrove trees dataset was used as control points and groundtruthing for the created Digital Surface Model (DSM).

\subsubsection{Data Processing}

We estimated the tree's location and height based on point clouds created by the Structure from Motion (SfM) photogrammetry method. Three-dimensional point clouds derived from SfM photogrammetry produced conservative and realistic measures of tree heights [12]. Alongside with point clouds, a DSM, Digital Terrain Model (DTM), and an orthomosaic were also generated from these processes [13].

The workflow comprises of three phases, namely pre-processing, processing, and post-processing. The workflow in point clouds generation and processing is illustrated in Figure 3. Pre-processing is mainly related to data acquisition including flight route planning, GCP placement and processing of overlapped images with SfM Photogrammetry. After the data is acquired, we process the images in commercial SfM photogrammetry software Agisoft Metashape Professional 1.6.1 (Agisoft LLC, St. Petersburg, Russia). The workflow is in general as follows: (1) photo alignment, (2) photo marking, (3) dense point clouds generation, (4) exporting dense point clouds, and (5) DSM and orthomosaic generation. A detailed description of this workflow can be read in the Appendix A, Table A1.

Since the UAV camera cannot penetrate the mangrove canopy, the DSM includes vegetation and any above ground covers. Therefore, on the next workflow, we processed the point clouds to estimate the DTM. Orthomosaic was created by using surface information provided by the DSM and orthorectifying of the overlapping images.

The processing phase consists of nine steps, which are quality checking, clipping, indexing, tiling, sorting, noise removal, ground classification, height normalisation, and generating the Canopy Height Model (CHM). Details in this phase are described in Figure 4. We used LASTools (rapidlasso $\mathrm{GmbH}$, Gilching, Germany) to clean the artefacts. The Cloth Simulation Filter (CSF) algorithm [46], which is efficient to extract the bare earth in lidR package [47], was employed for ground classification. As the first step, we assess the quality and information, e.g., number of points, projection, and point density with lasinfo module. Dense point clouds derived from SfM photogrammetry still contain noise and uncertainties $[48,49]$. Therefore, to get an optimal application in the mangroves environment, a cleaning procedure should be considered. The waterbody is the main noise contributor of the SfM photogrammetry point clouds. We visually inspected the orthomosaic and draw a polygon which excludes water and selected the area of interest. The raw point clouds were then clipped based on the polygon with lasclip module. Next, we tiled and indexed the clipped point clouds into a smaller tile of $40 \times 40 \mathrm{~m}$ and added a buffer that was $20 \%$ of the tile size. The tiling procedure is useful to decrease the computational time by taking advantage of parallel computation. Another consideration is that, the free licensed LASTools has a point limitation about 1 15 million points [50]. Therefore, tiles should be adjusted with the allowable number of points as attached to the license. The tiled points were then sorted to rearrange the points into a space-filling curve order. Afterward, we reclassified the highest points, find the highly isolated points in the dense forest, to create a temporary ground classification. Next, we mapped all the points located $0.2 \mathrm{~m}$ below the temporary ground as noise. These high and low noise were removed with the lasthin and lasnoise module. The cleaned photogrammetry point clouds then were processed with the CSF algorithm in the lidR package to define the ground 
points. An exhaustive manual revision of the ground-no ground classification was done in the dense forest to avoid ground misclassification. The point clouds were created only from what is visible to the camera within the path not penetrating the canopies, because of that only vegetation tops/canopies were included. Therefore, careful manual revision had to be made. Finally, points were height-normalised by replacing the height of each point to the relative height of the ground-classified points. Subsequently, we converted the height-normalised points into CHM and the ground-classified points into DTM.

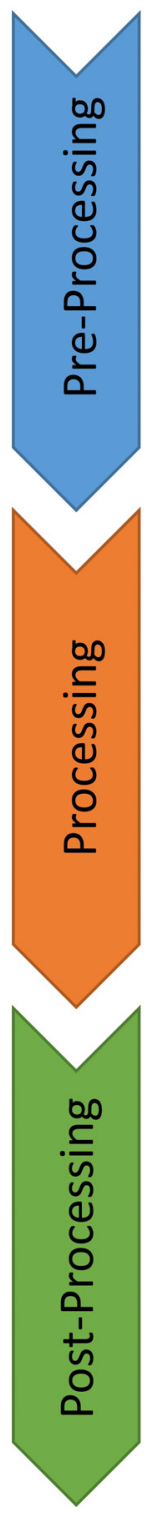

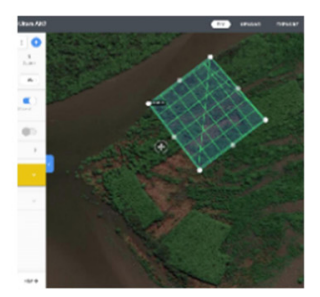

Flight Planning

+ Drone Flight

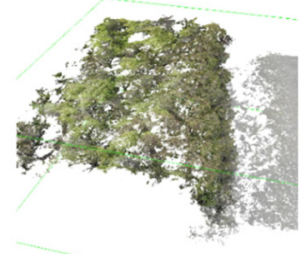

Point Clouds

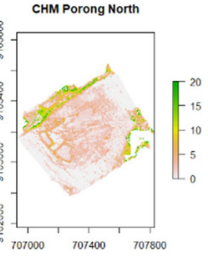

Canopy Height Model (CHM)

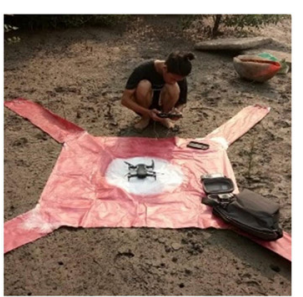

\section{Ground Control} Points (GCP) Identification

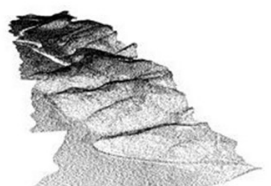

\section{LAStools}

Point Clouds

Noise

Cleaning

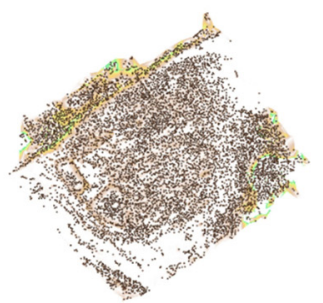

Tree Locations and Height

lidR package

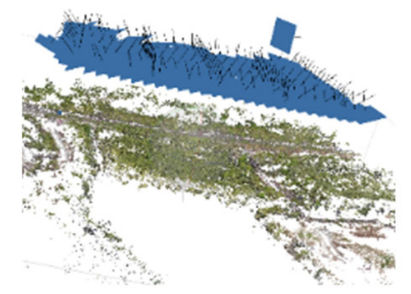

SfM Photogrammetry with Agisoft Photoscan

Figure 3. The workflow of the unmanned aerial vehicle (UAV)-based point clouds generation and processing.

In the post-processing phase, we used a CHM which is a gridded canopy model with $5.3 \mathrm{~cm}$ resolution. To locate individual trees in this very high-resolution CHM, the lidR 'tree_detection' provides two algorithms_Layer Stacking [51] and Local Maximum Filter (LMF) [52]. We set the LMF algorithm parameters window size to $5 \mathrm{~m}$ [15], a minimum height of $1.37 \mathrm{~m}$, and a circular moving window shape which represent the crown of a mangrove tree. The resulting data CHM were tree location $(x, y)$ and tree height $(z)$. The detected trees were manually checked to avoid errors [12]. 


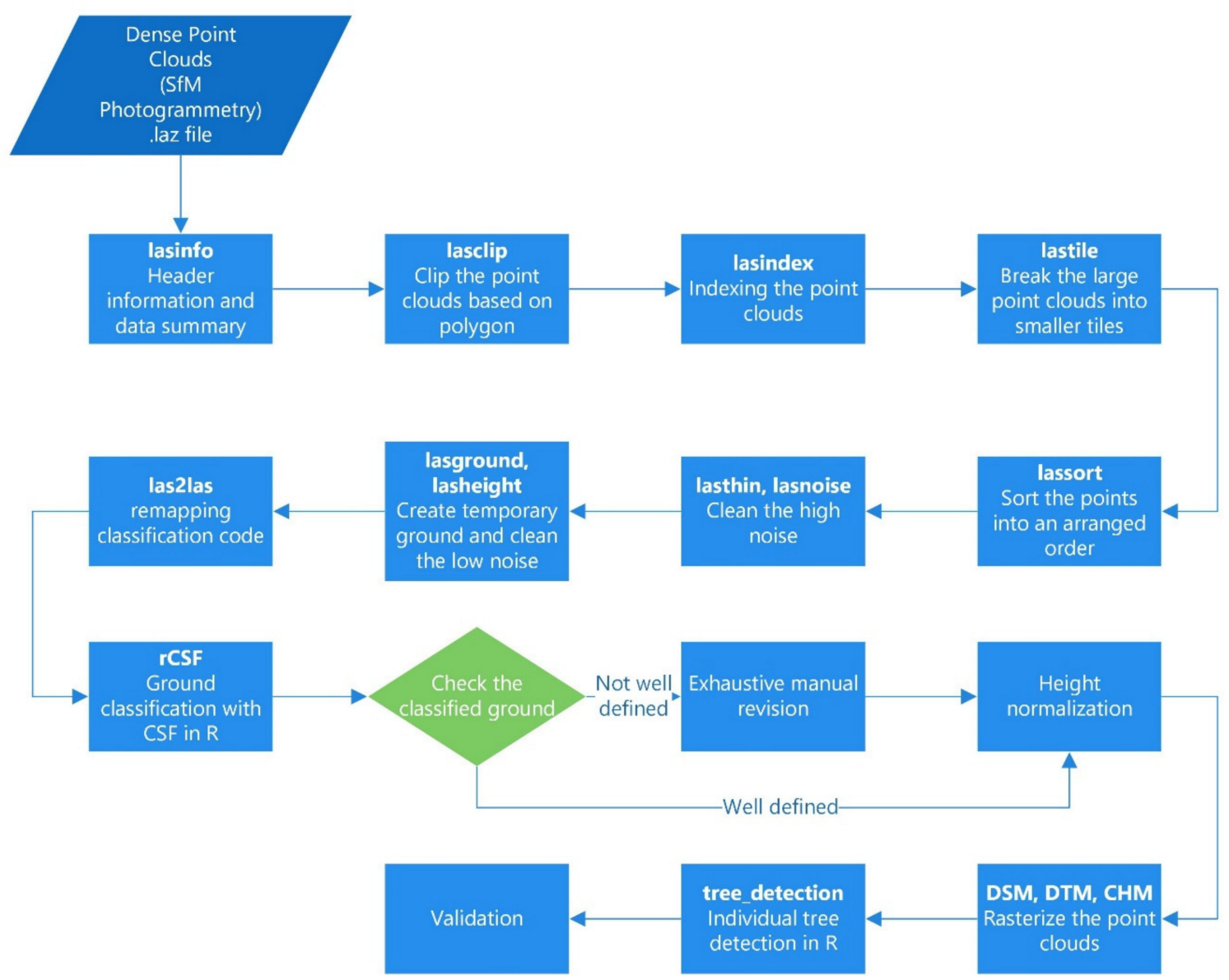

Figure 4. Working steps of the processing and post-processing phase of the point clouds.

\subsubsection{Tree Detection Validation}

The latest forest inventory was conducted by the Ministry of Marine Affairs and Fisheries (MMAF) in 2010 [53,54]. Therefore, we could not directly validate presence of individual trees detected in CHM. Most of the tree inventory collected during the fieldwork was located around the edge of mangrove forests. Therefore, we performed visual interpretation undertaken by the three researchers [15]. We pre-selected $30 \times 30 \mathrm{~m}$ plots reflecting the plot size as in traditional forest inventories. For each of the two delta lobes three plots were chosen, one being located at the centre, another at the northern and still another at the southern edge of the forest. The background of the researchers is (1) a groundwater engineer with no experience in ecology and remote sensing, (2) a hydraulic engineer with basic experience in remote sensing and no knowledge in ecology, and (3) a coastal engineer with basic knowledge in ecology and advanced knowledge in remote sensing. The horizontal accuracy of the detected trees and validation data can be quantified with widely used guidelines by the National Standard for Spatial Data Accuracy (NSSDA) [55] to measure the positional accuracy of the spatial datasets [56].

\subsection{Satellite Data and Processing}

Google Earth Engine (GEE) has been used as a tool to perform climate and hydrology and natural disaster analysis, and image processing, land use/land cover classification (LU/ LC), and urban planning [57,58]. GEE consists of petabytes of science-ready datasets and is equipped with high performance computing that can be accessed through an application programming interface (API) that is available in JavaScript and Python [59]. Some notable applications of GEE are, for instance, the Global Mangrove Watch [10], global forest cover change [60], global surface water changes [61,62], global shoreline 
changes [63], and continent level agricultural mapping [64]. To understand the mangrove extent development, we processed satellite imagery, such as Landsat 7/8 and Sentinel 1/2, in GEE with Python package geemap [65].

\subsubsection{Available Dataset}

We used combinations of satellite imagery from four satellites constellations available and science-ready in the GEE platform, i.e., Landsat 7 (L7), Landsat 8 (L8), Sentinel 1 (S1), and Sentinel 2 (S2). S1 and S2 are satellite constellations developed by ESA (European Space Agency) along with other constellations such as Sentinel 3 and 5. S1 and S2 satellites hold the sensors that are suitable for the mangrove classification study. S1 satellite carries a dual-polarisation C-band Synthetic Aperture Radar (SAR) instrument [66,67]. Each S1 scene in GEE has been pre-processed with the Sentinel-1 Toolbox and is science ready [68]. We employed Sentinel-1 SAR Ground Range Detected (GRD) products with $10 \mathrm{~m}$ spatial resolution with available dataset in GEE ('COPERNICUS/S1_GRD') from October 2014. The S2 satellite carries a Multispectral Instrument (MSI) with 13 spectral bands: $10 \mathrm{~m}$ resolution RGB and NIR, $20 \mathrm{~m}$ red edge and SWIR, and $60 \mathrm{~m}$ atmospheric band $[69,70]$. The S2 MultiSpectral Instrument (MSI) Level-1C products were used with available dataset in GEE ('COPERNICUS/S2') from June 2015. L7 and L8 are satellite constellations developed by a joint program of the USGS and the NASA. Within the GEE platform, L7 scenes have been atmospherically corrected using LEDAPS [71,72] and L8 using LasRC [73,74] (USGS Landsat Surface Reflectance Tier 1). Clouds, shadow, water, and snow were masked with the CFMASK algorithm [71,73,75]. The L8 Surface Reflectance Tier 1 ('LANDSAT/LC08/C01/T1_SR') which is available from April 2013 onwards and Landsat 7 Surface Reflectance Tier 1 ('LANDSAT/LE07/C01/T1_SR') dataset available from January 1999 onward were employed in this study.

Seasonal varying precipitation, flood control measures, and diversion operations are likely to influence the sediment yield. Mangrove flowering and seedling dispersal periods are also influenced by the season. By considering those conditions and dynamics on the delta, we proposed to map mangrove extent on a seasonal time scale. We mapped the mangrove extent that represents dry season (May and August) and wet season (November and February). A composite from one-month scenes of the particular month was created with the median value of the selected bands and indices for mangrove classification for optical sensor (S2, L7, L8). A mean function was applied for the satellite with SAR instrument (S1) $[76,77]$. The median value was chosen because it is less affected by outlier values that arise, for instance, from pixels affected by clouds or snow during the masking procedures [75]. To optimise the dataset availability and account for mangrove-mudflat dynamics, we employed the combination of S1 and S2 during the period of November 2015 to November 2019. The combination of optical S1 and S2 SAR was reported to improve the classification accuracy $[12,76,78,79]$. L8-based classification was for the period of August 2013 to August 2015, and L7-based classification was from dry season 2009 to dry season 2012. An exception has been made for L7-based classification. The L7 series of scenes has gaps due to Scan-Line Connector (SLC) failure or stripping problem [80]. Therefore, instead of using the one-month scenes we applied median values of full seasons (six months for each) during 2009-2012. Since in that period the diversion operation had just begun and the LUSI Island reclamation project had been conducted, we observed less mangrove succession in the delta. A presentation of the seasonal classification with a single map for the period of 2009-2012 is considered sufficient. All available datasets in a particular classification period were used to generate a cloud-free composite and improve the classification accuracy $[76,78]$.

\subsubsection{Vegetation Indices}

We assessed the mangrove vegetation cover by way of four optical-related vegetation indices that are widely used in land cover characterisation $[14,78,81,82]$, i.e., NDVI (Normalised Difference Vegetation Index) [83], NDMI (Normalised Difference Moisture 
Index) [15], EVI (Enhanced Vegetation Index) [84], and SAVI (Soil-Adjusted Vegetation Index) [85]. The $\mathrm{S} 1$ images were first pre-processed with a speckle filter (Lee refined) at a window size of $7 \times 7$ pixels $[81,86]$. A ratio channel $(\mathrm{VV} / \mathrm{VH})$ from the backscattering was generated. Lastly, the mean value of all S1 images was employed. This mean function makes the $\mathrm{S} 1$ composite less susceptible to variation in image acquisition [76,77]. With this additional dataset, each S1 mosaic had two bands and one index, while S2, L7, and L8 had 10,6 , and 7 spectral bands, respectively, and each was composed of four vegetation indices (Table 1). Table 2 specifies the vegetation indices formulas used in the analysis. Figure 5 describes the flowchart of the image processing procedure.

Table 1. Datasets used as input for each satellite constellation product.

\begin{tabular}{ccc}
\hline Mission & Bands/Indices & Metric \\
\hline Sentinel-1 & VV, VH, VV/VH & mean \\
\hline Sentinel-2 & B2-B8, B8A, B11-12, NDVI, NDMI, EVI, SAVI & median \\
\hline Landsat-7 & B1-5, B7, NDVI, NDMI, EVI, SAVI & median \\
\hline Landsat-8 & B2-8, NDVI, NDMI, EVI, SAVI & median \\
\hline
\end{tabular}

Table 2. Vegetation indices formulas used for the optical sensor.

\begin{tabular}{ccccc}
\hline Indices & Formulas & S-2 & L-7 & L-8 \\
\hline NDVI & $(\mathrm{NIR}-\mathrm{R}) \div(\mathrm{NIR}+\mathrm{R})$ & $(\mathrm{B} 8-\mathrm{B} 4) \div(\mathrm{B} 8+\mathrm{B} 4)$ & $(\mathrm{B} 4-\mathrm{B} 3) \div(\mathrm{B} 4+\mathrm{B} 3)$ & $(\mathrm{B} 5-\mathrm{B} 4) \div(\mathrm{B} 5+\mathrm{B} 4)$ \\
\hline $\mathrm{NDMI}$ & $(\mathrm{NIR}-\mathrm{SWIR}) \div(\mathrm{NIR}+\mathrm{SWIR})$ & $(\mathrm{B} 8-\mathrm{B} 11) \div(\mathrm{B} 8+\mathrm{B} 11)$ & $(\mathrm{B} 4-\mathrm{B} 5) \div(\mathrm{B} 4+\mathrm{B} 5)$ & $(\mathrm{B} 5-\mathrm{B} 6) \div(\mathrm{B} 5+\mathrm{B} 6)$ \\
\hline \multirow{2}{*}{$\mathrm{EVI}$} & $2.5 \times((\mathrm{NIR}-\mathrm{R}) \div(\mathrm{NIR}+6 \times \mathrm{R}$ & $2.5 \times((\mathrm{B} 8-\mathrm{B} 4) \div(\mathrm{B} 8$ & $2.5 \times((\mathrm{B} 4-\mathrm{B} 3) \div(\mathrm{B} 4$ & $2.5 \times((\mathrm{B} 5-\mathrm{B} 4) \div(\mathrm{B} 5$ \\
& $-7.5 \times \mathrm{B}+1)$ & $+6 \times \mathrm{B} 4-7.5 \times \mathrm{B} 2+1)$ & $+6 \times \mathrm{B} 3-7.5 \times \mathrm{B} 1+1)$ & $+6 \times \mathrm{B} 4-7.5 \times \mathrm{B} 2+1)$ \\
\hline \multirow{2}{*}{ SAVI } & $(\mathrm{NIR}-\mathrm{R}) \times 1.5 \div(\mathrm{NIR}+\mathrm{R}+0.5)$ & $(\mathrm{B} 8-\mathrm{B} 4) \times 1.5 \div(\mathrm{B} 8+$ & $(\mathrm{B} 4-\mathrm{B} 3) \times 1.5 \div(\mathrm{B} 4+$ & $(\mathrm{B} 5-\mathrm{B} 4) \times 1.5 \div(\mathrm{B} 5+$ \\
& & $\mathrm{B} 4+0.5)$ & $\mathrm{B} 3+0.5)$ & $\mathrm{B} 4+0.5)$ \\
\hline
\end{tabular}

\subsubsection{Land Cover Classification}

A supervised land cover classification with machine learning algorithm was employed in GEE. Several of those algorithms have been embedded in GEE. These classifiers are Classification and Regression Tree (CART), Random Forest (RF), NaiveBayes, and Support Vector Machine (SVM) [59]. Wetland mapping, as in mangrove swamps, is one of the most challenging areas for remote sensing. RF supervised classification is reported to have the highest accuracy among widely used machine learning algorithms, e.g., K-Nearest Neighbour (KNN), SVM, Maximum Likelihood (ML), and CART [76,87]. RF comprises a collection of tree-structured classifiers to make prediction [88]. RF is more robust to noise and size reduction of the training set than CART [89], easier to implement than SVM [90], and is particularly suitable to handle high dimensional remote sensing data [91].

The land cover classification was conducted using the following workflow: (1) training data collection, (2) initiating classifier and adjusting parameters, (3) train the classifier with training dataset, (4) classify the image based on the trained dataset, and (5) accuracy checking. In the first step, the training dataset is provided from the very high-resolution orthomosaic created on the UAV data processing. We created three classifications (water, mangroves, and mudflat area) by plotting region of interests (ROIs) which represent these classifications. As the intertidal mudflat varies over time by tidal variation, proper consideration should be made by not only referencing the mudflat's ROI based on the orthomosaic but also considering the median composite in November 2019. The ROIs polygons were made in QGIS as a shapefile and uploaded to GEE as assets. Next, sample points were created based on supervised ROIs. Accuracy of RF classification is sensitive to the sample size and spatial distribution [92]. Within each stratum, which is based on supervised ROIs, the stratums are randomly sampled [93]. Stratified random sampling 
function in GEE was used to sample the training data. Cochran's formula (1) was employed to determine sample size by assuming an unknown proportion for each class [94].

$$
n_{0}=Z^{2} \frac{p q}{e^{2}}
$$

Here, $n_{0}$ is the sample size per class, $p$ is the proportion of the population which has the class in question, $q=1-p, \mathrm{Z}$ is the $\mathrm{z}$-value for the given confidence, $e$ is the margin of error. The samples were subdivided into a $70 \%$ training set and $30 \%$ of validation [88]. In the next step, to optimise the computational performance, RF classifier with 200 decision trees [78] was initiated and trained as several studies suggested 100-500 as the optimal number $[89,91,95-97]$. The trained dataset then is used to classify the composite.

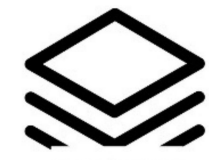

Landsat-7

Dry Season

2009 - Dry

Season 2012

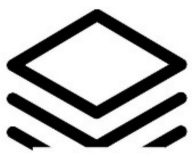

Landsat-8

Aug 2013-

Aug 2015

Cloud Masking, Clipping, Calculate Indices, Median all over images

\section{Landsat-7}

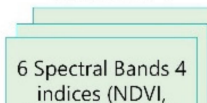

NDMI, EVI, SAVI)

$\downarrow$

17 Composite
November 2019
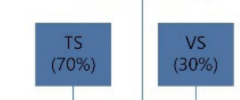

$\square$

Train Random Forest Mode

$\checkmark$

Classified Input Imagery

$\downarrow$

Accuracy Assessment

Accuracy Assessment
(OA, PA, CA, Kappa) L7 Composite Dry Season
2009 - Dry Season 2012

Classified Input Imagery
Landsat-8

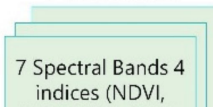
NDMI, EVI, SAVI)
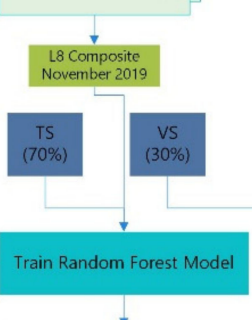

Classified Input Imagery

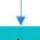

$\checkmark$

Accuracy Assessment

(OA, PA, CA, Kappa)

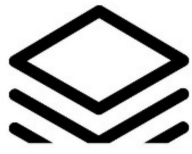

Sentinel-2

Nov 2015 -

Nov 2019

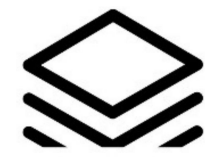

Sentinel-1

Nov $2015-$ Nov 2019

Filter Instrument Mode IW Filter (VV, VH), Filter Descending, Radar Speckle Filtering, Mean all over images

\section{Sentinel-2

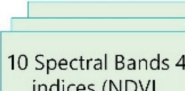 indices (NDVI, $\mathrm{NDMI}, \mathrm{EVI}, \mathrm{SAVI})$}

Sentinel-1

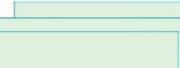

$\sigma^{\circ} \mathrm{V}, \sigma^{\circ} \mathrm{VH}, \mathrm{V} / \mathrm{VH}$

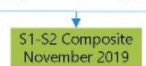

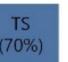
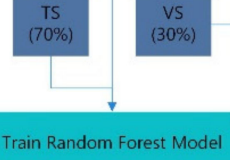

Train Random Forest Mode

Classified Input Imagery

Accuracy Assessment
(OA, PA, CA, Kappa)

Figure 5. Flowchart of the satellite imagery processing in Google Earth Engine (GEE) with Landsat 7, Landsat 8, Sentinel 1, and Sentinel-2. The UAV orthomosaic is used as the training and validation dataset. 


\subsubsection{Accuracy Assessment and Validation}

We used accuracy assessment functions embedded in GEE for those parameters. The final ground-truthing is based on the VHR orthomosaic derived from UAV image acquisitions in November 2019. We used the confusion error matrix with these parameters: Overall Accuracy (OA), Kappa Coefficient, Producer Accuracy (PA), and Consumer Accuracy $(\mathrm{CA})[87,90]$. The OA is calculated by summing the number of correctly classified values and divided by the total number of values. PA is determined by comparing the number of correctly classified values of a particular class and number of reference pixels of the same class, while CA can be calculated by dividing the number of correctly classified values of a particular class and number of classified pixels in the class [98]. The OA, PA, and CA are expressed as percentage, with $100 \%$ accuracy representing a perfect classification. Kappa measures the difference between the actual agreement in the error matrix and the chance agreement that is indicated by the row and column total [93]. A kappa value of 0 represents no agreement, and a value of 1 indicates perfect agreement.

\section{Results}

This section outlines the result of drone-based point clouds, tree detection and validation, and satellite-based mangrove extent change over time.

\subsection{Point Clouds}

In total, we processed $2860 \mathrm{UAV}$ images (2020 images for north delta lobe and $840 \mathrm{im}$ ages for the southern delta lobe), which is equal to an average of 200 images per grid. SfM Photogrammetry provided point clouds, DSM, and orthomosaic for each delta lobe. The generated raw point clouds had 400.5 million and 136.6 million points, which correspond to average point densities of $951.25 \mathrm{~m}^{-2}$ and $736 \mathrm{~m}^{-2}$ for the northern and southern delta lobes, respectively. The derived DSM has a resolution of $5.33 \mathrm{~cm} /$ pixel and an orthomosaic with $2.66 \mathrm{~cm} /$ pixel resolution. The products in total covered an area of $0.44 \mathrm{~km}^{2}$ and were corrected based on GCPs with a total error of $0.06 \mathrm{~m}$. The discrepancy between the planned flight area and the product is generated from other areas captured during the UAV image acquisition.

A small subset of the point clouds is shown in Figure 6. The set of figures illustrates the step-by-step point clouds processing. Figure 6a shows subtle noise yielded on the SfM-based point clouds. The raw point clouds were refined by classifying the high and low noise, resulting in cleaned points as depicted in Figure 6d. The ground-classified points with the CSF method were then evaluated, especially those situated below the dense vegetation since SfM-based point clouds provide no information below the canopy cover. Hence, an exhaustive manual revision was conducted by checking and correcting the classified ground points. The final point classification categories chosen for the analysis were non-ground (1), ground (2), high vegetation (5), and noise (7). The final result of the point cloud processing is a height-normalised point clouds that can be described with all elevations were normalised with respect to the ground, i.e., an elevation of $0 \mathrm{~m}$. Figure 7 shows DTM and DSM derived from the final classification of the point clouds.

\subsection{Canopy Height Model (CHM) and Tree Detection}

The height normalised point clouds were rasterised to a CHM with a resolution of $0.1 \mathrm{~m}$, and subjected to the individual tree detection. The 'tree_detection' function in the lidR package with the LMF algorithm was adjusted to detect mangrove trees above the breast height. The individual trees derived from the algorithm can be observed in Figure 8 . 


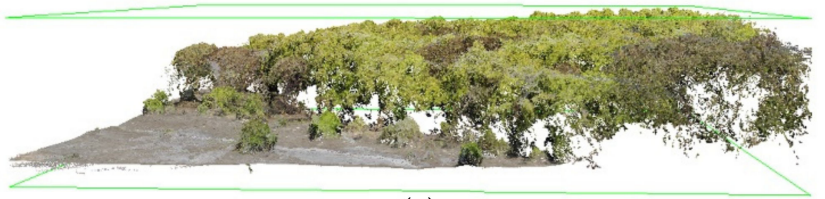

(a)

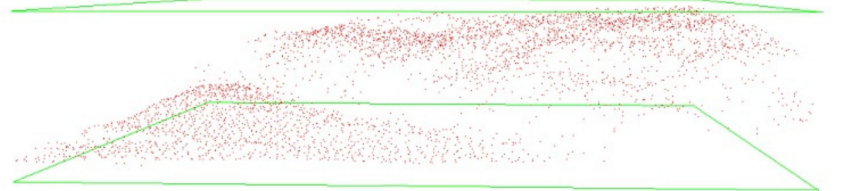

(b)

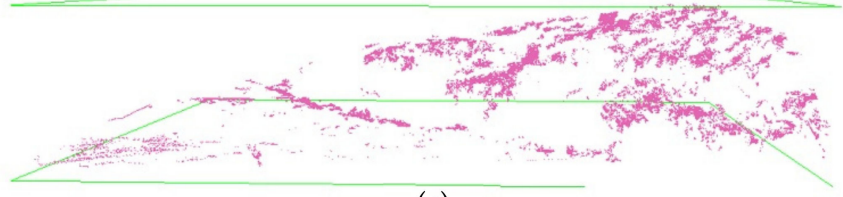

(c)

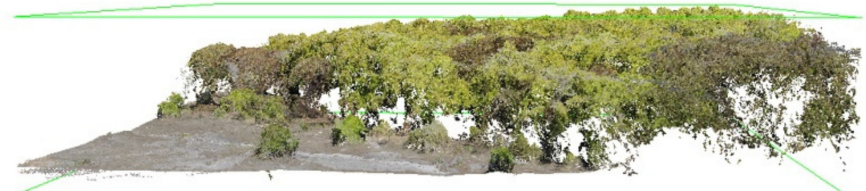

(d)

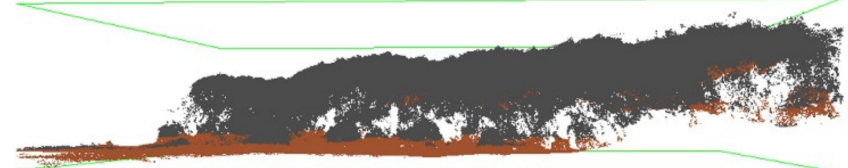

(e)

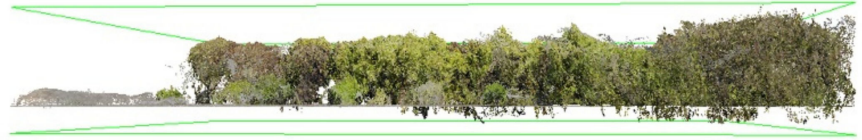

(f)

Figure 6. Point clouds processing: (a) raw point clouds, (b) the thinned 20\% elevation percentile points, (c) high noise-classified points, (d) cleaned photogrammetry point clouds, (e) ground points classification (brown colour represents ground points and grey represents non-ground), (f) height normalisation.

The root mean square error (RMSE) analysis of the individual tree detection based on fieldwork data and visual inspection is described in detail in Appendix B, Table A2. The RMSE value for tree location was $0.23 \mathrm{~m}$ on average. All three validators provided similar RMSE $E_{\mathrm{r}}$ with values ranging $0.15,0.28$, and $0.25 \mathrm{~m}$, while the maximum $\mathrm{RMSE}_{\mathrm{r}}$ was $0.48 \mathrm{~m}$. As observed, the number of the detected trees for the dense mangrove forest was underestimated, whereas it was more accurate in the sparse mangrove forest.

The CHM-derived height demonstrated that the mangroves' median height is $3.5 \mathrm{~m}$ in the southern delta while the northern delta with its older mangroves had a median height of $4.2 \mathrm{~m}$. As shown in Figure 9, the northern delta had bi-modal tree height distribution. The distribution is likely correlated to the mangrove planting activities in 2016. Corresponding rectangular shaped mangrove areas can be clearly seen in Figure 7a. 

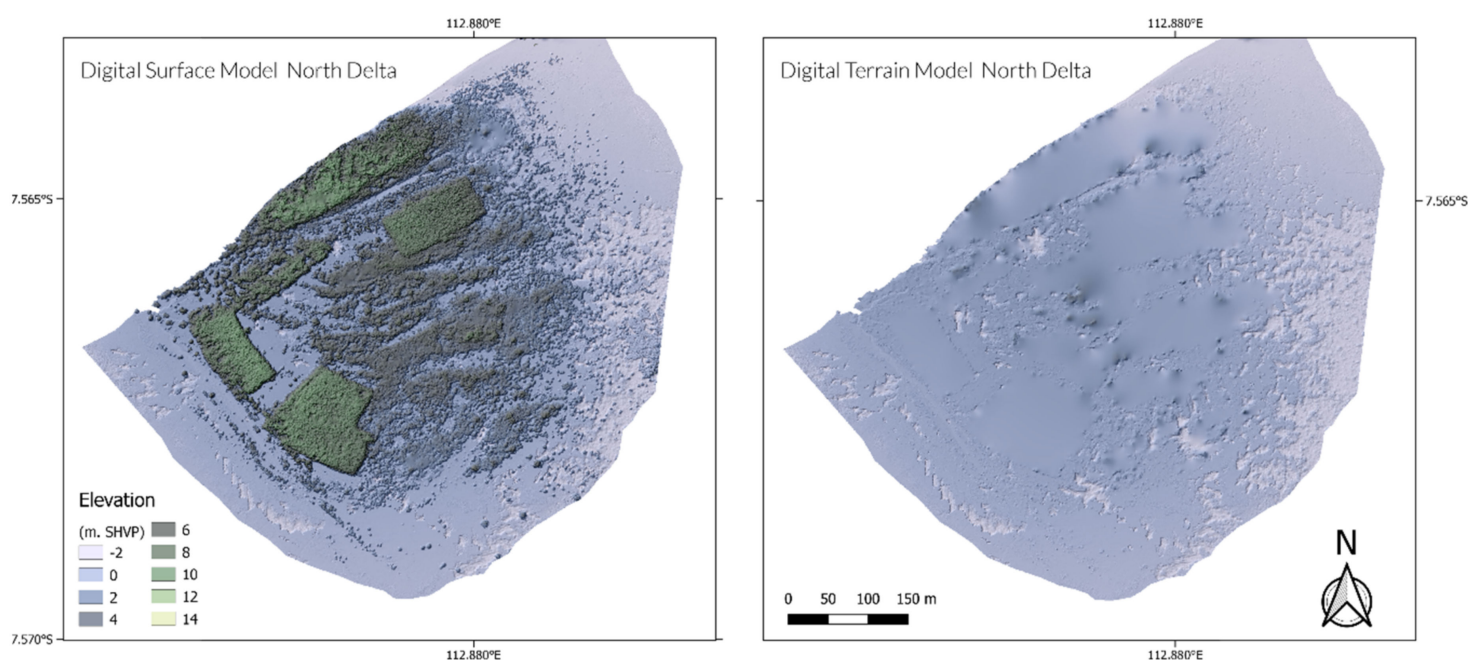

(a)
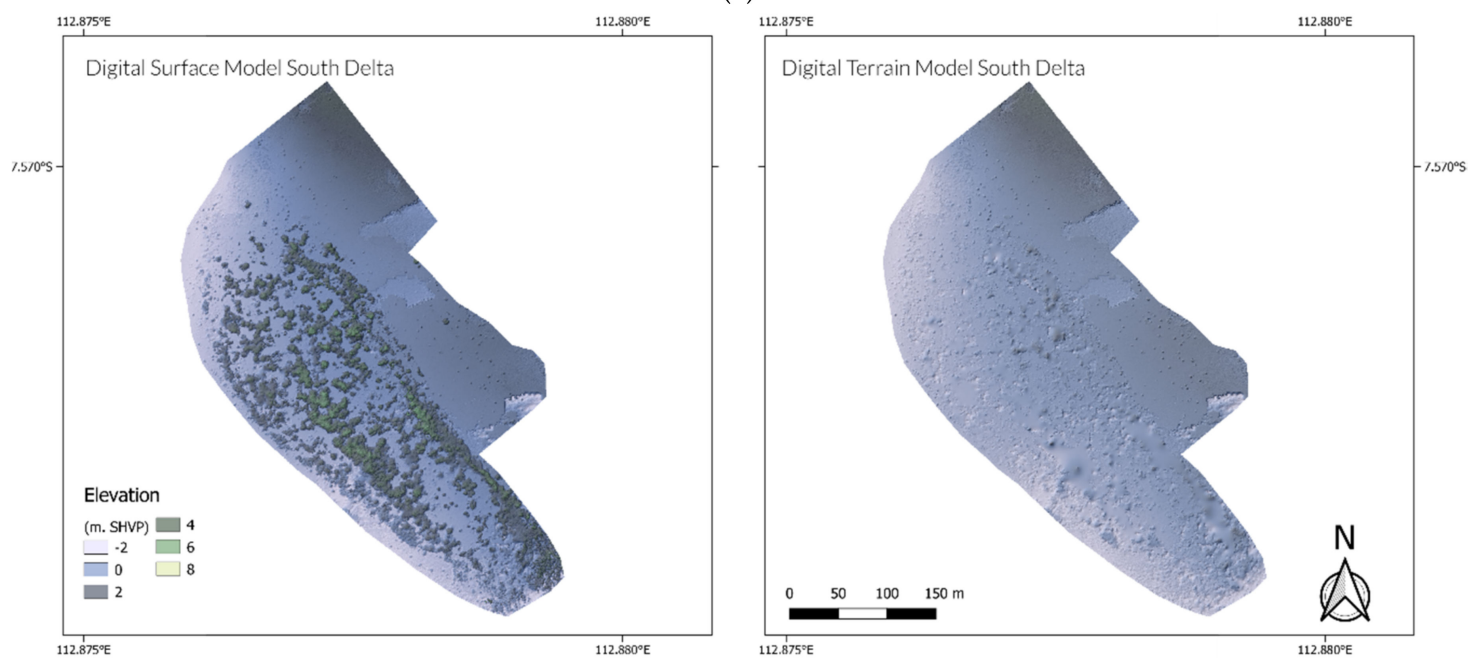

(b)

Figure 7. (a) Digital Surface Model (DSM) and Digital Terrain Model (DTM) of the northern delta and (b) DSM and DTM of the southern delta.
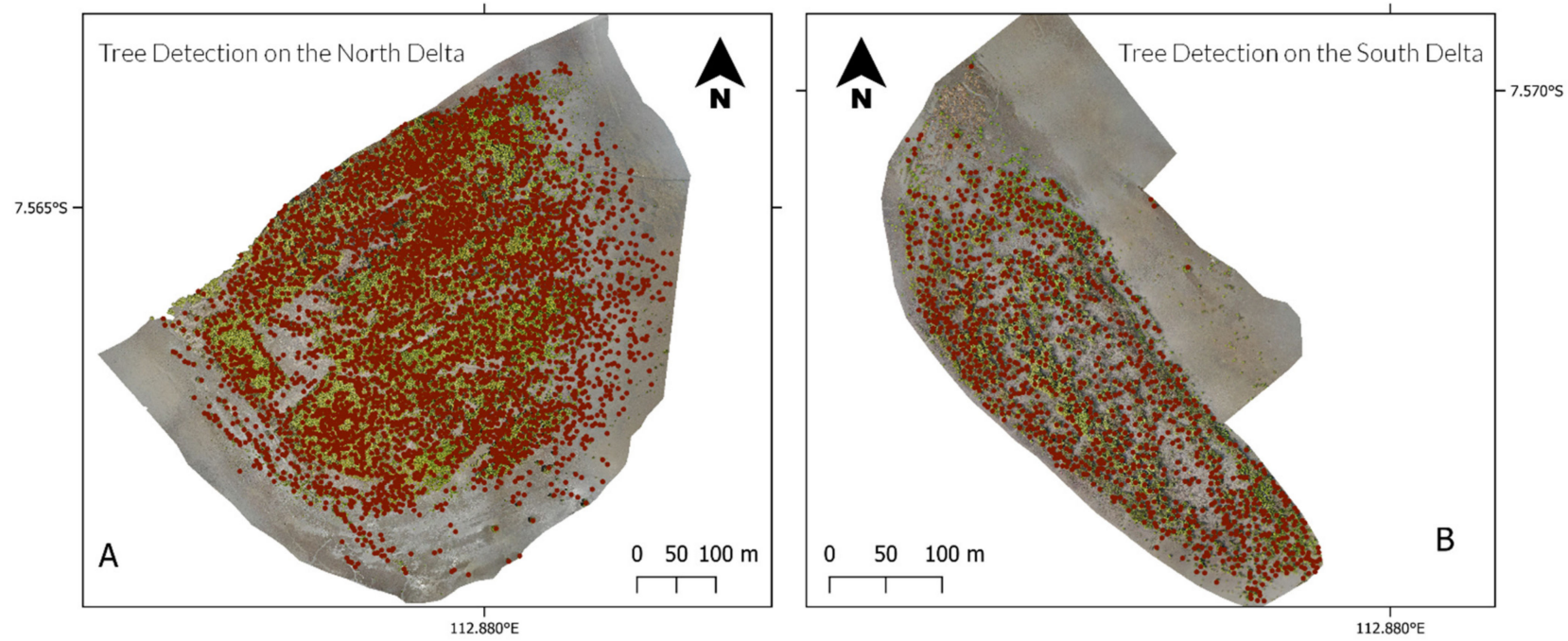

Figure 8. The detected individual tree as represented here as the red dots derived from UAV Structure from Motion (SfM) photogrammetry in (A) northern delta and (B) southern delta. 


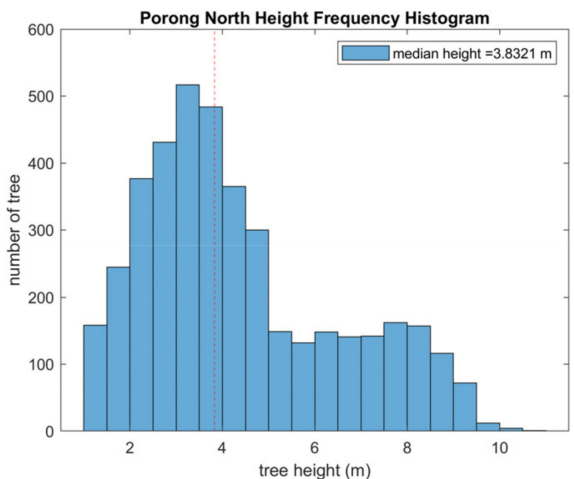

(a)

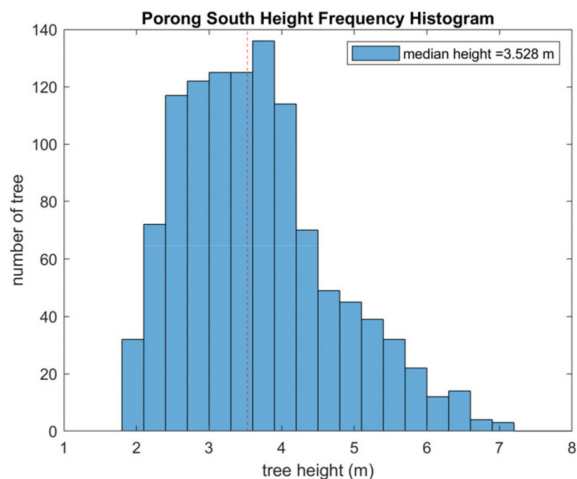

(b)

Figure 9. The detected mangrove trees height frequency histogram of (a) the north delta and (b) the south delta.

\subsection{Mangrove Extent and Age Estimation \\ 3.3.1. Mangrove Extent}

Figures 10 and 11 illustrate the development of the mangrove extent from 2009 to 2019. Figure 11 presents the result of the mangrove classification based on L7 (2009 Dry season-2012 Wet season), L8 (August 2013-August 2015), and the combination of S1-S2 (November 2015-November 2019). It can be observed that the mangrove belt expansion has strongly developed in the Porong River mouth. The mangroves on LUSI Island are clearly visible and have continuously expanded after the construction in 2011 (Figure 11). On the northern delta lobe, mangroves appeared in 2016 followed by the southern delta lobe in 2018. The land conversion to fish ponds in the hinterland is apparent as well in the figures.

Figure 10 provides an illustrative visualisation of the mangrove dynamics. Starting in 2006 the mangrove forests tended to expand seawards. The mangroves in northern and southern delta lobes contributed significantly to this. Considering the time series map, it is likely that the southern delta mangrove will be attached to the LUSI Island within the next few years.

The time series of the mangrove extent has been extracted for both on the region of interest (ROI) (Figure 12a) as well as for the LUSI Island-delta lobes (Figure 12b). Both areas exhibit a similar positive trend of development. Generally, it varies with season. The mangroves area recedes during the transition from dry to wet season and the mangroves regrow during the wet to dry season. However, the delta lobes' mangroves have a slightly different seasonal pattern. As in Figure 12b, the mangrove's seasonal variation is less pronounced. It is likely because it is more isolated and is affected less by human activities.

\subsubsection{Accuracy Assessment of Porong's Mangrove Classification}

Four confusion matrices of L7, L8, and S1/2 based classification show high accuracy when compared with the UAV ground reference data. The reference data was subdivided into $70 \%$ fraction of the total sample points (cf. Section 2.3.3) for training purposes, equal to 808 points for all classes. The rest (30\% of the sample points) or 347 points in total were used for validation samples. The values of Overall Accuracy (OA), Kappa Coefficient, Producer Accuracy (PA), and Consumer Accuracy (CA) of all the classifications were all above $98 \%$. L7 or L8 alone are already excellent sources for the classification of the onemonth composite, but the combination of S1 and S2 is even superior to those. The trained OA, Kappa, PA, and CA of S1-S2 classification were all 100\%. Due to the SLC error, the trained L7 classification generated from a six-month mean composite also resulted in 100\% OA, Kappa, PA, and CA values. The L8-trained OA, Kappa, PA, and CA were 99.88\%, 0.99, $99.65 \%$, and $99.62 \%$, respectively. 


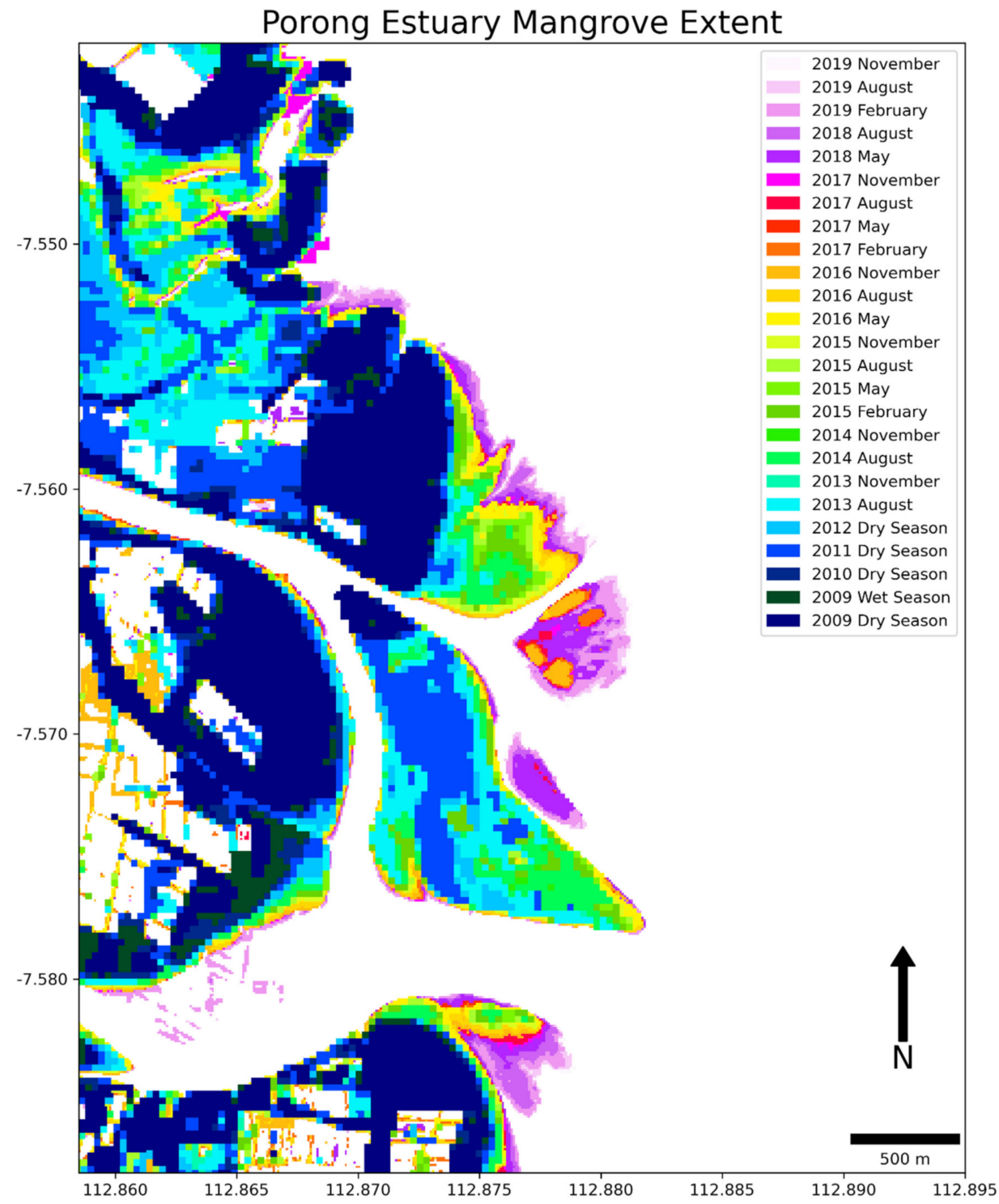

Figure 10. Time series of porong mangrove extent derived from Landsat 7, Landsat 8, and Sentinel 1-Sentinel 2 imagery (the time-series animation is provided as an online material: Animation S1).

The validation accuracies also showed consistently excellent values similar to those of the training. The combination of S1-S2 has a value of $100 \%$ for all confusion matrices. The L8-validated OA, Kappa, PA, and CA were 99.39\%, 0.99, 97.92\%, and 98.39\%, respectively. The L7-validated OA, Kappa, PA, and CA were $99.54 \%, 0.99,97.83 \%$, and $98.18 \%$, respectively.

\subsubsection{Age Map}

The age map (Figure 13) was estimated and referenced to November 2019 and derived backward to 2009. The age map indicates that the mangrove expansion of forests being attached to the mainland began in 2014. In comparison, the isolated forests (on the delta lobes) were found to have started expanding in 2016, most likely initiated by the mangrove planting in the northern delta, in contrast to the natural mangrove succession that took place in the southern delta. 

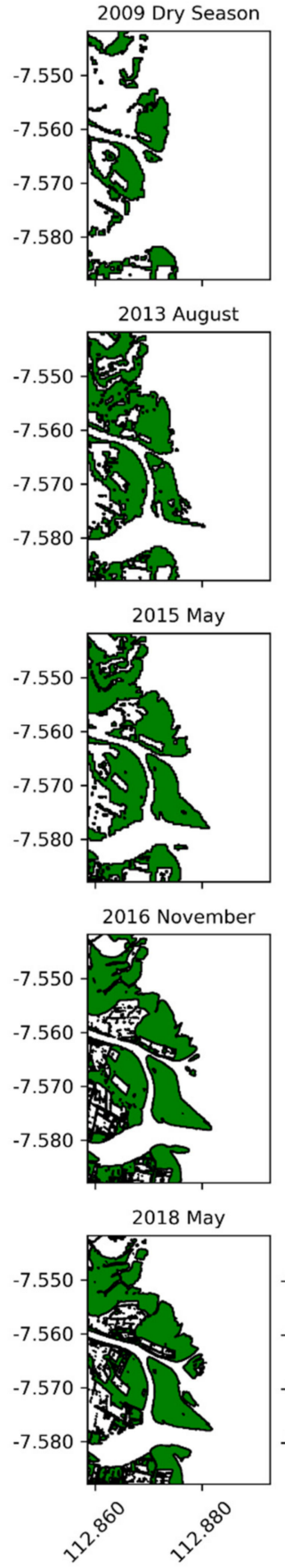

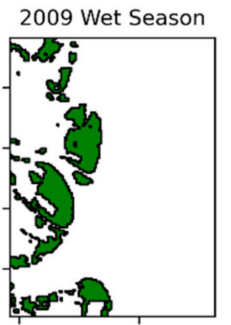

2013 November
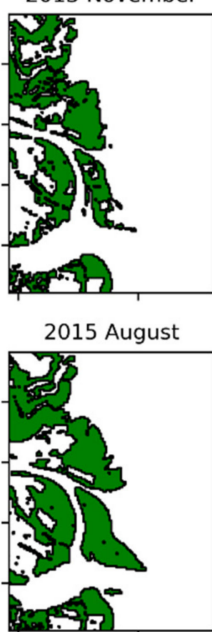

2017 February

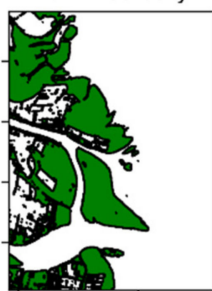

2018 August

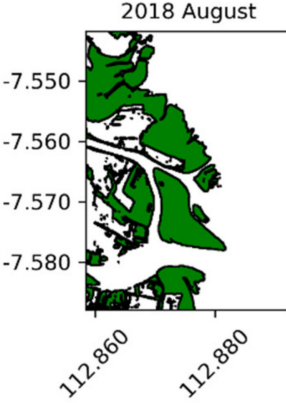

Porong Classification
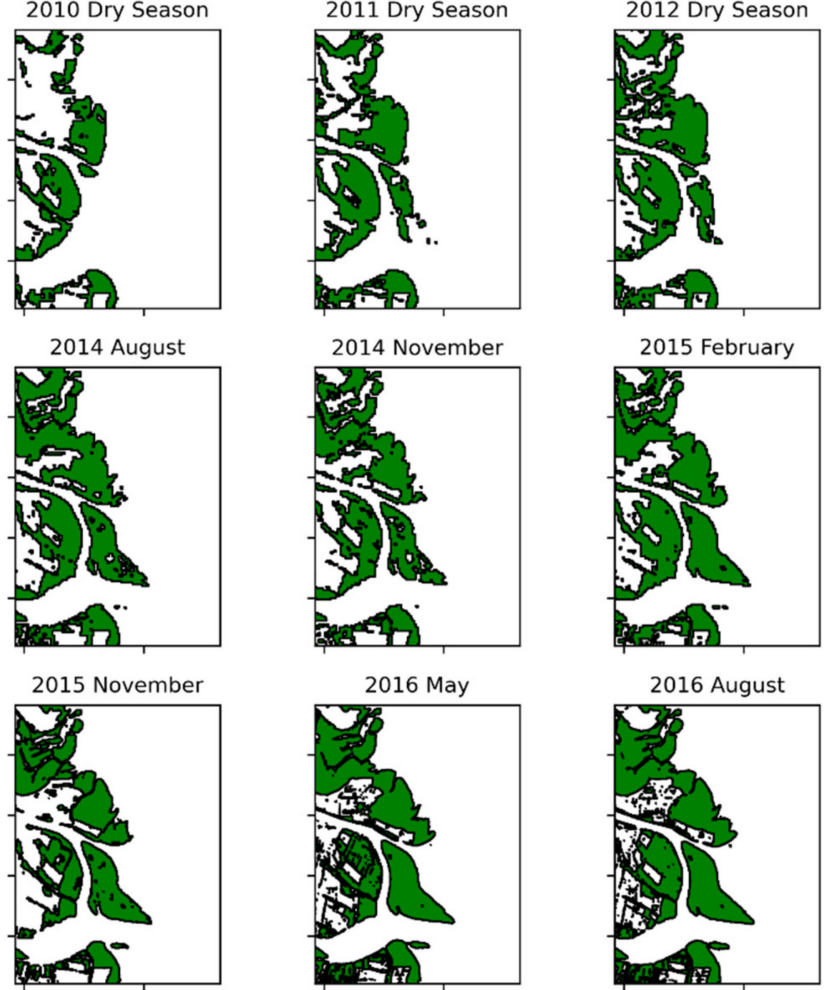

2017 August
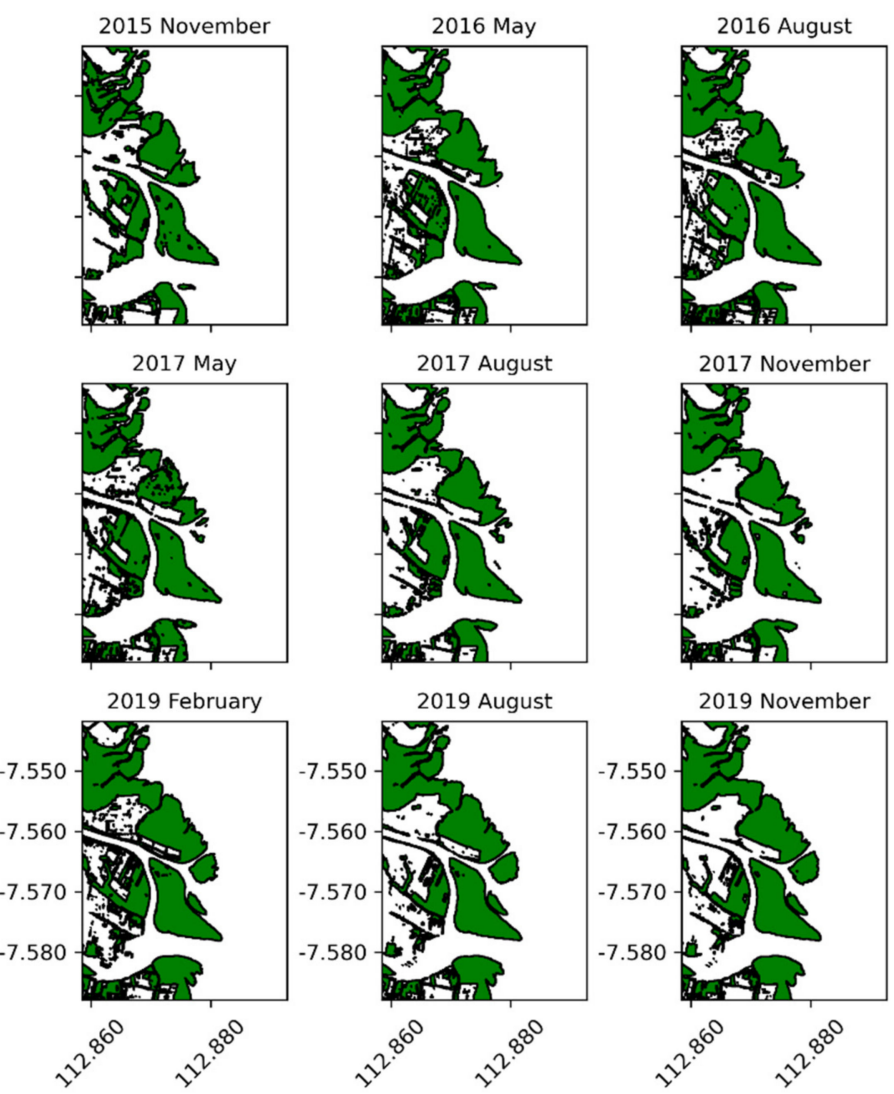

Figure 11. Details of the mangrove extent estimated by satellite imagery from the 2009 dry season to November 2019.

By taking advantage of the age map and the high-resolution CHM, a relationship of mangrove height dependent on stand age was setup for the two Porong delta lobes. A mean height distribution across the mangrove age map was calculated by clipping the mangroves' age polygon to a CHM raster. Figure 14 compares the age-height relationships from the delta lobes' mangroves. The northern delta mangroves were consistently taller than the southern ones at the same stand age. By only taking the mangrove trees into account that were taller than $1.3 \mathrm{~m}$, the average annual mangrove growth of the northern delta amounted to $2.26 \mathrm{~m} \mathrm{yr}^{-1}$. In contrast, the mangroves in the southern delta had an annual mangrove growth rate of $1.71 \mathrm{~m} \mathrm{yr}^{-1}$. 


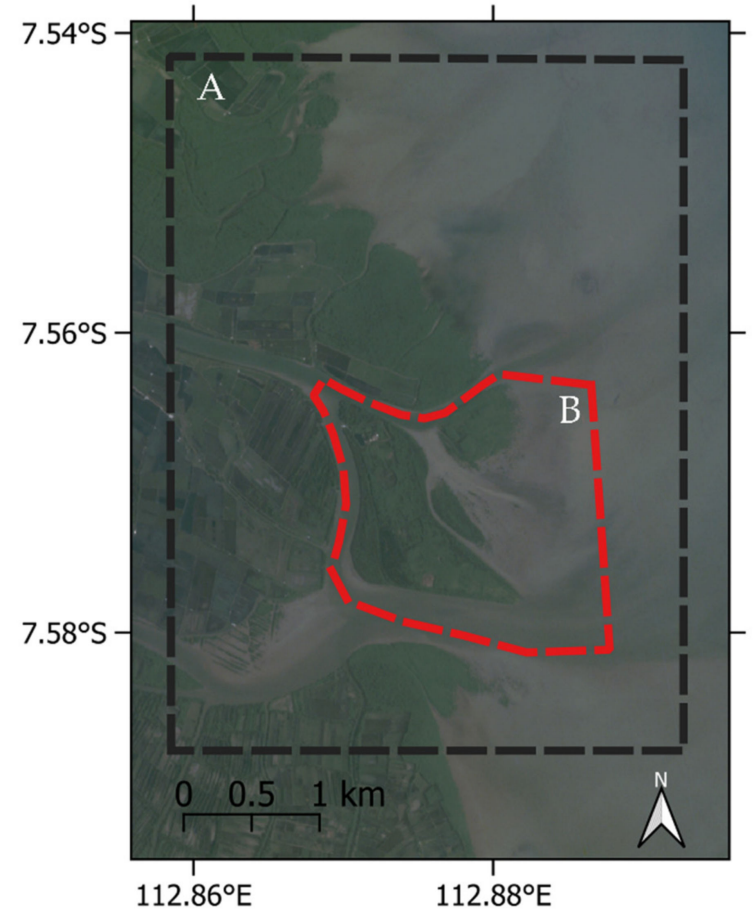

Image Source: Planet Tropical Analyzed Analytic Monthly October 2020
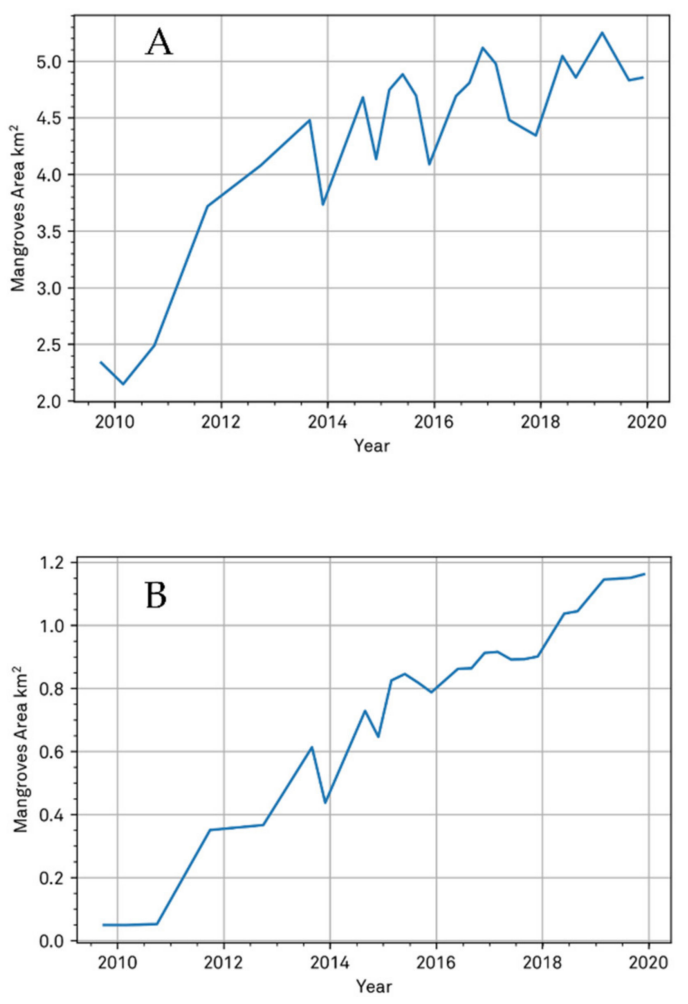

Figure 12. Time series of mangrove extent area development on (A) the region of interest (ROI) extends from $112.8585^{\circ} \mathrm{S}$, $-7.5418^{\circ} \mathrm{E}$ to $112.8927^{\circ} \mathrm{S},-7.5879^{\circ} \mathrm{E}$ and focusing on (B) the Porong Estuary and the newly developed delta lobes which obviously exhibits an increasing trend of area development after 2011. The right figures show the time-series of mangrove area development for each region $(\mathbf{A}, \mathbf{B})$.

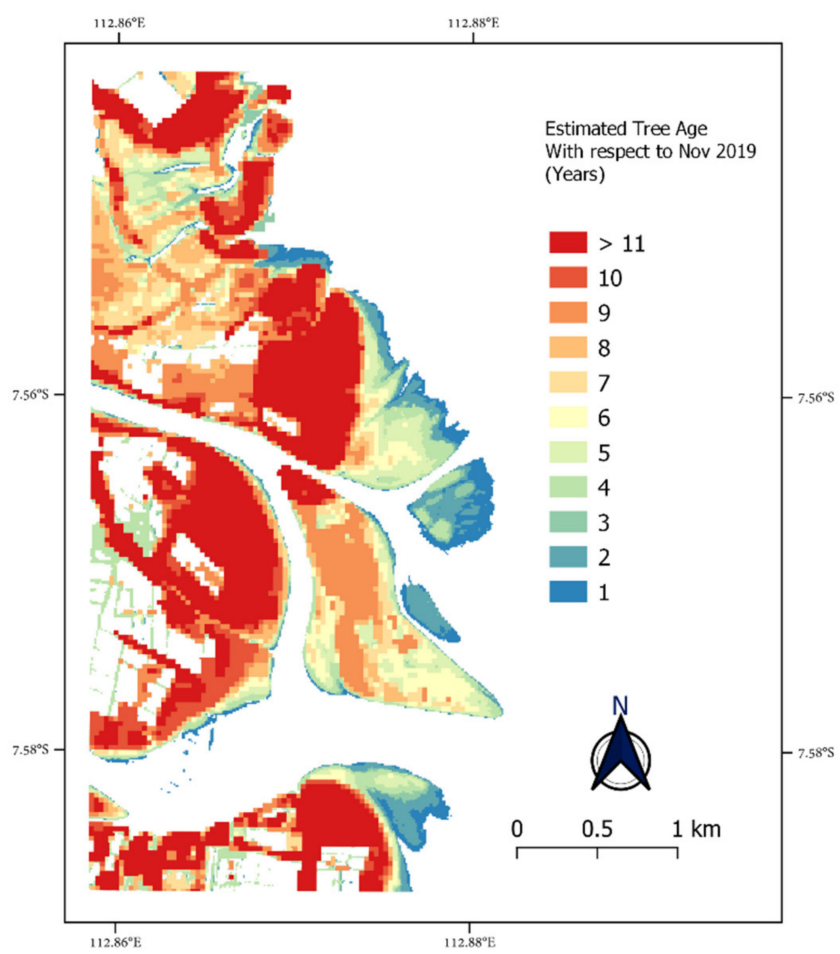

Figure 13. Map of mangroves age distribution in Porong Estuary as estimated with respect to the reference period of November 2019. 


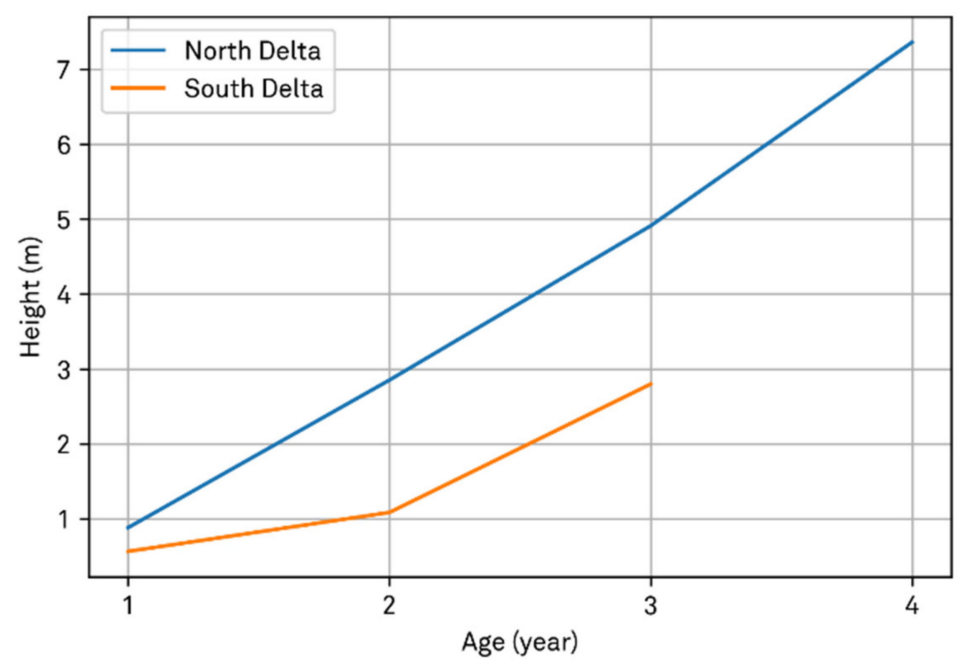

Figure 14. Relationship of the mangrove height dependent on stand age on Porong Delta Lobes.

\section{Discussion}

The study aimed to quantify the mangrove dynamics arising from the massive LUSI mudflow diversion operation that followed the extreme mud volcano eruption, in Sidoarjo, Indonesia. Our investigation started in January 2009 and continued until November 2019. This investigation of mangrove dynamics combined usage of UAV-based and satellite analyses with GEE cloud computing. This approach included the successful retrieval of mangrove biophysical properties in terms of canopy height and the individual position of mangrove trees (Figure 8) as well as a time series of mangrove belt development (Figure 10). This approach resulted to a new set of mangrove extent maps for our study location that is not covered by other existing products such as the WMA [1] and GMFD v1 [8] that were released in 2000. The GCMFC-21 [9], GMW v2.0 [10] and at the national-level provided by the Indonesian National Institute of Aeronautics and Space (LAPAN) [99], whose latest product at the time of writing dates from 2012, 2016, and 2019, respectively. The mangrove dataset provided by the GMW v2.0 from the period of 1996, 2007, 2008, 2009, 2010, 2015, and 2016, while LAPAN products were for the period of 2014, 2016, and 2019. Therefore, from those datasets the mangrove dynamics in Porong Estuary cannot be deduced. The spatial and temporal resolution of those dataset is not sufficient as Porong has been experiencing extreme mud influx from LUSI and its transformation has been so rapid. This study resulted in a higher temporal resolution and detailed three monthly mangrove classification and their biophysical properties, especially in the highly dynamic delta lobes that expand seaward.

\subsection{UAV-Based Mangrove Forest Inventory}

The derived tree locations were in close correspondence with field inventory data and expert analyses at an RMSE $\mathrm{r}$ in the order of $20 \mathrm{~cm}$. However, since the low-cost UAV is equipped with an RGB camera system, the estimated tree location is limited to the description of the canopy top inherent in the CHM. It is different from the LiDAR system where the beam is able to penetrate the dense canopy cover. The UAV-based SfM photogrammetry method tended to underestimate the number of individual trees, even though it has a higher accuracy in the sparse mangrove forest. Based on the result, the low accuracy in the dense forest of the northern delta lobe is likely due to the mangrove plantation programme that has created a more homogenous canopy and an almost flat CHM. This prevented complete detection of all treetop positions. However, despite the underestimated tree location, considering that colonising mangrove species during primary succession is shade-intolerant, therefore, the loss in detection might be marginal, in particular when the canopy is still sparse. The estimated individual positions of the trees can give us more information regarding the height distribution of the mangrove's trees and 
density (Supplementary Materials S1). As shown in Figure 9 we can observe the influence of mangrove planting on the north delta to the height variation indicated by the bimodal distribution (Figure 9a).

Despite its limitation, the UAV-based tree detection offers the advantages of lower technical requirements and lower costs when compared to a LiDAR system [39]. With miniaturisation, increasing proliferation, and advancement in sensor technology, the possibility arises of adding multispectral sensors to accuracy of the UAV-based method while keeping it lightweight and low-cost. The image acquisition was conducted for five days or equal to 8.8 hectares/day since it was limited by the time frame of the optimum sunlight and battery capacity. The UAV survey in this study was conducted by two people. In comparison, traditional mangrove forest inventory with three experienced surveyors needs two complete days (seven hours / day) to sample 0.05 hectare of the forest [15]. Thus, UAV-based forest inventory is likely to increase the possibility for frequent and rapid mangrove monitoring. Moreover, this method can be further developed as citizen science monitoring. With an off-the-shelf drone, pre-planned flight, open tutorial, and validation procedure, the public can be involved in this kind of mangrove monitoring programme. Depending on the needs, the UAV-based SfM photogrammetry is useful to estimate mangrove biophysical properties from the plot level up to the landscape-level. Moreover, another product generated in the workflow, for instance, the DTM is useful in studying the biogeomorphology to understand the feedback loop of vegetation and the environment forcing.

\subsection{Mangrove Belt Expansion Identification in Google Earth Engine}

The expansion of the mangrove belt has been substantiated with the supervised land cover classification. We have evidenced a total of 11 years of mangrove development (2009 2019) with high accuracy (more than 98\%). Cloud computation with GEE to our advantage, we generated three monthly mangrove maps, with the exception of sixth-monthly maps during the period of 2009-2012. Most importantly, our map series has higher frequency than the above-mentioned global mangrove products.

\subsection{Seasonal Pattern of Mangrove Dynamics}

Based on the resulting maps, it is apparent that the year 2016 marked the start of the positive mangrove expansion, which seen in Figure 10 and the time-lapse animation in the Supplementary Animation S1. There were two of the largest expansion areas in the Porong River mouth contributing $24 \%$ of the total mangrove area extracted inside the ROI as of November 2019 (Figure 12). It is highly likely that the mudflow diversion procedure has promoted mangrove belt expansion in Porong Estuary. Mud pumping disposal of LUSI discharged extra sediment supply thereby providing a suitable environment that enhanced mangrove expansion. Figure 11 provides detail of the significant increase of mangrove extent both on the ROI and focusing on the estuary. Dredging operation and the completion of LUSI Island construction in 2011 have contributed to the prominent increase of the mangrove area.

The mangrove expansion followed a seasonal pattern as Figure 12 clearly indicates. We observed recession of the mangrove extent during the transition of dry to wet season and regrowth during the wet to dry season. The wet season has the highest sedimentation rates related to the mudflow pumping operation in LUSI. The mud is disposed of in the wet season and stored in the reservoir during the dry season. The seasonal pattern in Porong was also indicated in the study by Sidik et al. (2016) [21]. In principle, net development trend of the mangrove area is positive. Investigated further, we can see amplitude of the high-low signal differs in the period of 2013-2017 from that in 2018-2019. In 2013-2017, we can see low mangrove extent in the wet season followed by the high regrowth in the dry season. In contrast, from 2018 to 2019, we observe only a slight decrease in the wet season and a high roughly two-fold increase in the dry season. Focusing on the Porong river mouth, as shown in Figure $12 \mathrm{~b}$, the seasonal fluctuation is also recognised but is 
less pronounced as in Figure 12a. The graphs reveal continuous expansion until August 2013, irrespective of the region, thus no recession visible in both regions. From August to November 2013, there is a sudden recession, i.e., sharp decrease of area in region A and slightly less in region $\mathrm{B}$. The recession took place in the middle of the dry season and the beginning of the wet season, thus at the end of the dry season. There is recovery occurring from November 2013 until August 2014, where recovery is more pronounced for region A (February and May clear satellite images are lacking in 2014). The recovery occurred during the wet to dry season. It seems that the recession occurred at the end of the dry season while recovering and return to expansion happens in the middle of the wet season and the first half of the dry season. This 2013 recession-recovery behaviour repeats in 2014-2017, where the fluctuation is noticeable in region A and less in region B. It is likely in the beginning mangroves start growing on the newly deposited, homogeneously distributed mud since its sediment attributes are rather suitable for their growth. Mangroves have access to water during wet season as well as during dry season. However, because of their existence, further sediment is deposited at the margin of the forest. This possibly transforms them into the basin mangrove type in certain areas, more so in the landward direction, less so on the delta lobes. When the trees start generative production, i.e., propagule production, at an age of three years seedling that are known to be more sensitive to salt and drought might die under the extreme conditions at the end of the dry season in the basins. This condition has developed from the interplay of vegetation and geomorphological processes-namely, the massive sediment load. Studies reported buried pneumatophore leads to mangrove mortality, for example in Mekong Delta [100]; high sedimentation concentration reduces the oxygen level in the mangrove's root [21,101]; and an enhanced of growth of Micronesia trees that is possibly due to associated decreases in root zone salinity [102].

The delta lobes' mangroves response to high sedimentation rates is generally appear as lack of growth instead of a decrease. It is likely because the delta lobes are relatively isolated and therefore less affected by human activities, such as land conversion to fishponds that is obvious in the maps. Given the sharp decrease-increase pattern in Figure 12a (period 2014-2018) and slight decrease-increase as Figure 12a (period 2018-2019) Figure 12b it is likely that anthropogenic activities played an additional role. However, as a verification of that role is beyond the scope of this article, we suggest further investigation of this topic.

\subsection{Mangroves' Age Class Estimation}

The age map (Figure 13) was derived to understand the mangroves succession. When it is combined with the CHM, we can estimate the annual growth rate of the mangrove trees (Figure 14). The age map indicates a difference in the trend of mangrove expansion for those located in the river mouth and on the mainland. Expansion in the river mouth was altered by the LUSI Island's construction and the built-up of the delta lobes. It is likely that the mangrove planting programme affected the northern delta's spatial tree height variation. Apparently, it is also visible in the age-height relationship displayed in Figure 14. As the mangroves on the northern delta were planted, the mangroves tended to be in average two times taller in their first year than its southern counterparts. However, the data used to derive the age-height graph in this article is probably not long enough; for instance, the southern delta provides only three years of observation. Thus, two growth rates for the relationship, which is insufficient for performing statistical tests. Nevertheless, mangrove growth rates had a similar trend for both locations, despite a difference likely due to the mangrove planting. Moreover, the graph demonstrates the advantage of combining UAVbased VHR data and satellite imagery to characterise the mangrove structural attributes that need a large workforce if done traditionally.

\subsection{Implications of the Study}

To our knowledge, this study presents the first attempt to explore the mangrove dynamics in a prograding delta setting by integrating UAV and multiple sources of satellite imagery (L7, L8, S1, and S2) in GEE. Studies to classify mangrove forest have been 
conducted in the last two decades $[8,10]$. They were based not only on one source but also on the combination of multiple satellite sources $[12,14,103,104]$ and became more popular with the advent of GEE. The resulting three-monthly classification maps are more frequent than the commonly produced annual mangrove maps. The frequent monitoring is deemed necessary in this environmental setting, since the sediment influx continues at an unprecedented rate, promoting rapid delta development and mangrove belt expansion. The results of the UAV and the entire methodology presented here shows the advantage of using an off-the-shelf drone. The CHM and individual tree locations present important structural attributes to characterise the mangrove forest. It is essential as there is likely a much closer linkage between diameter at breast height ( $\mathrm{dbh}$ ) and height rather than between crown radii and dbh. Accurate information of mangrove biophysical structure is critical for the ecologist, coastal manager, or policymaker.

\section{Conclusions}

The LUSI mud volcano eruption, arguably the largest mud eruption in the world, certainly affects the downstream landscape development. Particularly with the diversion operation that conveys a large amount of mudflow sediment into the river that eventually stimulates a rapid progradation of the delta compared to pre-LUSI conditions. This offers a unique opportunity to analyse mangrove dynamics on a rapidly prograding delta. We created time series of mangrove extent maps and mangrove biophysical structure with the following steps: (a) biophysical properties retrieval using UAV-based SfM photogrammetry; (b) three-monthly classification of mangrove areas using L7, L8, S1, and S2 in Google Earth Engine; and (c) derivation of mangrove age maps based on the satellite imagery. This improvement enables us to capture the highly dynamic setting in the study area. Moreover, the off-the-shelf UAV offers an efficient yet accurate technique to retrieve the important structural attributes, such as individual tree location and canopy height. When combined with satellite imagery analyses, the information can be used to characterise the mangrove forest and assess the effect of excessive mudflow discharge on the delta and mangrove development.

The proposed approaches allowed us to monitor the dynamics of mangrove extent and structural attributes in a rapidly prograding delta. The random forest supervised classification demonstrated a high accuracy (OA $>99.39 \%$, kappa value 0.99 , PA $>97.83 \%$, and CA $>98.18 \%$ ). The highest accuracy was obtained in the classification from the combined Sentinel 1 and 2, while the lowest resulted from the Landsat 7. The 11 years of mangrove extent mapping provided evidence of an overall positive trend in mangrove extent overlaid by seasonal variation. The receding mangrove area is detected during the transition from dry to wet season and regrow during the wet to dry season. The individual trees height and position derived from UAV showed the different distribution of the north and south delta lobes that is likely related to the mangrove planting.

The method enabled us to retrieve rapid and accurate information on mangrove biophysical properties with an off-the-shelf drone. Moreover, in combination with GEE based cloud computing, it is possible to derive a high spatiotemporal resolution mangrove extent map. The combination of UAV-derived spatial tree structure and the satellite-derived maps are needed to support fast and frequent mangrove monitoring that will be valuable for the ecologists, coastal managers, or policymakers.

Supplementary Materials: The following are available online at https:/ / www.mdpi.com/2072-429 2/13/6/1084/s1, Animation S1: Time series animation of Porong mangrove extent, Supplement S1 Mangrove trees density on the northern and southern delta lobes.

Author Contributions: Conceptualisation, S.M.B., M.v.d.W., U.G., and D.R.; methodology, S.M.B.; software, S.M.B.; validation, S.M.B.; formal analysis, S.M.B.; data curation, S.M.B.; writing-original draft preparation, S.M.B.; writing-review and editing, S.M.B., M.v.d.W., D.R., U.G., J.D., and J.R.; visualisation, S.M.B.; supervision, M.v.d.W. and D.R.; project administration, S.M.B.; funding acquisition, S.M.B. All authors have read and agreed to the published version of the manuscript. 
Funding: This research is funded by the Indonesia Endowment Fund for Education (LPDP) with grant number 201710220111567.

Data Availability Statement: The data presented in this study are available on request from the corresponding author.

Acknowledgments: S.M.B. gratefully acknowledges LDPD within their framework of BUDI-LN for its financial support. S.M.B. would like to extend his gratitude to Agisoft LLC for their support by providing five months Agisoft Metashape Profesional license for this research. S.M.B. wants to thank Amar Sajali from Miyazaki University for his support in the SfM photogrammetry section, Jadfan Sidqi Fidari, and Dian Chandrasasi for their support in validation section. S.M.B. would also thank Frida Sidik and Agus Setiawan from the Ministry of Marine Affairs and Fisheries who have offered valuable data and fruitful discussion about LUSI when we started this study.

Conflicts of Interest: The authors declare no conflict of interest.

\section{Appendix A}

Here we explain the settings of the pre-processing phase to generate 3D point clouds in the Agisoft Metashape Profesional. The settings in this appendix are for Agisoft Metashape Professional version 1.6 .3 build 10723 (64 bit). The detailed description is depicted in Table A1 below.

Table A1. Settings of the Agisoft Metashape Professional.

\begin{tabular}{|c|c|c|}
\hline Steps & Parameters & Value \\
\hline \multirow{8}{*}{ Align Photos } & Accuracy & 'High' \\
\hline & Generic Preselection & 'Yes' \\
\hline & Reference Preselection & 'Source' \\
\hline & Key Point Limit & 50,000 \\
\hline & Tie Point Limit & 4000 \\
\hline & Guided Image Matching & 'Yes' \\
\hline & Adaptive Camera Model Fitting & "Yes" \\
\hline & Camera Calibration & 'Enable Rolling Shutter Compensation' \\
\hline \multirow{4}{*}{ Dense Cloud Generation } & Quality & 'High' \\
\hline & Depth Filtering & 'Mild' \\
\hline & Calculate Point Colours & activate \\
\hline & Calculate Point Confidence & activate \\
\hline
\end{tabular}

\section{Appendix B}

The calculation of positional accuracy of the detected trees is following the guidelines by the NSSDA Part 3: National Standard for Spatial Data Accuracy [55]. We assessed the horizontal accuracy of the detected trees against the visual observation by the three observer and fieldwork measurement. The RMSE values were assessed using the following equations:

$$
\begin{aligned}
& R M S E_{x}=\frac{\sqrt{\sum_{i}\left(x_{\text {data }, i}-x_{\text {check }, i}\right)^{2}}}{n} \\
& R M S E_{y}=\frac{\sqrt{\sum_{i}\left(y_{\text {data }, i}-y_{\text {check }, i}\right)^{2}}}{n} \\
& R M S E_{r}=\sqrt{\text { RMSE }_{x}^{2}+R M S E_{y}^{2}}
\end{aligned}
$$

where $x_{\text {data }, i}, y_{\text {data }, i}$ are the coordinates of the ith check point of the dataset and $x_{\text {check, } i}$, $y_{\text {check, } i}$ are the coordinates of the ith check points of the independent source of higher accuracy and $n$ is the number of check point tested. The horizontal error at point $i$ is 
defined as in the Equation (A3). The results of the positional accuracy are shown in the tables below.

Table A2. Detected trees positional accuracy.

\begin{tabular}{|c|c|c|c|}
\hline Plots & RMSE $_{\mathbf{x}}$ & RMSE $_{\mathbf{y}}$ & $\mathrm{RMSE}_{\mathbf{r}}$ \\
\hline \multicolumn{4}{|l|}{ Observer 1} \\
\hline North 1 & 0.09 & 0.09 & 0.12 \\
\hline North 2 & 0.07 & 0.08 & 0.11 \\
\hline North 3 & 0.08 & 0.09 & 0.12 \\
\hline South 1 & 0.19 & 0.16 & 0.25 \\
\hline South 2 & 0.13 & 0.08 & 0.15 \\
\hline South 3 & 0.09 & 0.08 & 0.12 \\
\hline Average & - & - & 0.15 \\
\hline \multicolumn{4}{|l|}{ Observer 2} \\
\hline North 1 & 0.12 & 0.09 & 0.15 \\
\hline North 2 & 0.11 & 0.10 & 0.15 \\
\hline North 3 & 0.08 & 0.08 & 0.11 \\
\hline South 1 & 0.29 & 0.29 & 0.41 \\
\hline South 2 & 0.28 & 0.26 & 0.38 \\
\hline South 3 & 0.30 & 0.38 & 0.49 \\
\hline Average & - & - & 0.28 \\
\hline \multicolumn{4}{|l|}{ Observer 3} \\
\hline North 1 & 0.15 & 0.12 & 0.19 \\
\hline North 2 & 0.14 & 0.19 & 0.23 \\
\hline North 3 & 0.15 & 0.15 & 0.21 \\
\hline South 1 & 0.17 & 0.22 & 0.28 \\
\hline South 2 & 0.28 & 0.23 & 0.37 \\
\hline South 3 & 0.14 & 0.16 & 0.21 \\
\hline Average & - & - & 0.25 \\
\hline
\end{tabular}

\section{References}

1. Spalding, M.; Kainuma, M.; Collins, L. World Atlas of Mangroves; Taylor and Francis Group: London, UK, 2010; ISBN 978-1-84977-660-8.

2. Duke, N.C.; Nagelkerken, I.; Agardy, T.; Wells, S.; Van Lavieren, H.; Van Bochove, J.-W.; Sullivan, E.; Nakamura, T. UNEP World Conservation Monitoring. In The Importance of Mangroves to People: A Call to Action; United Nations Environment Programme: Nairobi, Kenya, 2014; ISBN 978-92-807-3397-6.

3. Murdiyarso, D.; Purbopuspito, J.; Kauffman, J.B.; Warren, M.W.; Sasmito, S.D.; Donato, D.C.; Manuri, S.; Krisnawati, H.; Taberima, S.; Kurnianto, S. The Potential of Indonesian Mangrove Forests for Global Climate Change Mitigation. Nat. Clim. Chang. 2015, 5, 1089-1092. [CrossRef]

4. Hill, J.W.; Bourke, L.A.; Horton, C.M.; Staples, T.L.; Lovelock, C.E. Limited Relationships between Mangrove Forest Structure and Hydro-Edaphic Conditions in Subtropical Queensland, Australia. Estuar. Coast. Shelf Sci. 2020, 106930. [CrossRef]

5. Bispo, P.D.C.; Pardini, M.; Papathanassiou, K.P.; Kugler, F.; Balzter, H.; Rains, D.; Dos Santos, J.R.; Rizaev, I.G.; Tansey, K.; Dos Santos, M.N.; et al. Mapping Forest Successional Stages in the Brazilian Amazon Using Forest Heights Derived from TanDEM-X SAR Interferometry. Remote Sens. Environ. 2019, 232, 111194. [CrossRef]

6. Gillis, L.; Bouma, T.; Jones, C.; Van Katwijk, M.; Nagelkerken, I.; Jeuken, C.; Herman, P.; Ziegler, A. Potential for Landscape-Scale Positive Interactions among Tropical Marine Ecosystems. Mar. Ecol. Prog. Ser. 2014, 503, 289-303. [CrossRef]

7. Walters, B.B.; Rönnbäck, P.; Kovacs, J.M.; Crona, B.; Hussain, S.A.; Badola, R.; Primavera, J.H.; Barbier, E.; Dahdouh-Guebas, F. Ethnobiology, Socio-Economics and Management of Mangrove Forests: A Review. Aquat. Bot. 2008, 89, 220-236. [CrossRef] 
8. Giri, C.; Ochieng, E.; Tieszen, L.L.; Zhu, Z.; Singh, A.; Loveland, T.; Masek, J.; Duke, N. Status and Distribution of Mangrove Forests of the World Using Earth Observation Satellite Data: Status and Distributions of Global Mangroves. Glob. Ecol. Biogeogr. 2011, 20, 154-159. [CrossRef]

9. Hamilton, S.E.; Casey, D. Creation of a High Spatio-Temporal Resolution Global Database of Continuous Mangrove Forest Cover for the 21st Century (CGMFC-21): CGMFC-21. Glob. Ecol. Biogeogr. 2016, 25, 729-738. [CrossRef]

10. Bunting, P.; Rosenqvist, A.; Lucas, R.; Rebelo, L.-M.; Hilarides, L.; Thomas, N.; Hardy, A.; Itoh, T.; Shimada, M.; Finlayson, C. The Global Mangrove Watch-A New 2010 Global Baseline of Mangrove Extent. Remote Sens. 2018, 10, 1669. [CrossRef]

11. Feldpausch, T.R.; Lloyd, J.; Lewis, S.L.; Brienen, R.J.W.; Gloor, M.; Monteagudo Mendoza, A.; Lopez-Gonzalez, G.; Banin, L.; Abu Salim, K.; Affum-Baffoe, K.; et al. Tree Height Integrated into Pantropical Forest Biomass Estimates. Biogeosciences 2012, 9 , 3381-3403. [CrossRef]

12. Navarro, J.A.; Algeet, N.; Fernández-Landa, A.; Esteban, J.; Rodríguez-Noriega, P.; Guillén-Climent, M.L. Integration of UAV, Sentinel-1, and Sentinel-2 Data for Mangrove Plantation Aboveground Biomass Monitoring in Senegal. Remote Sens. $2019,11,77$. [CrossRef]

13. Navarro, A.; Young, M.; Allan, B.; Carnell, P.; Macreadie, P.; Ierodiaconou, D. The Application of Unmanned Aerial Vehicles (UAVs) to Estimate above-Ground Biomass of Mangrove Ecosystems. Remote Sens. Environ. 2020, 242, 111747. [CrossRef]

14. Lucas, R.; Van De Kerchove, R.; Otero, V.; Lagomasino, D.; Fatoyinbo, L.; Omar, H.; Satyanarayana, B.; Dahdouh-Guebas, F. Structural Characterisation of Mangrove Forests Achieved through Combining Multiple Sources of Remote Sensing Data. Remote Sens. Environ. 2020, 237, 111543. [CrossRef]

15. Otero, V.; Van De Kerchove, R.; Satyanarayana, B.; Martínez-Espinosa, C.; Fisol, M.A.B.; Ibrahim, M.R.B.; Sulong, I.; MohdLokman, H.; Lucas, R.; Dahdouh-Guebas, F. Managing Mangrove Forests from the Sky: Forest Inventory Using Field Data and Unmanned Aerial Vehicle (UAV) Imagery in the Matang Mangrove Forest Reserve, Peninsular Malaysia. For. Ecol. Manag. 2018, 411, 35-45. [CrossRef]

16. Lagomasino, D.; Fatoyinbo, T.; Lee, S.; Feliciano, E.; Trettin, C.; Simard, M. A Comparison of Mangrove Canopy Height Using Multiple Independent Measurements from Land, Air, and Space. Remote Sens. 2016, 8, 327. [CrossRef] [PubMed]

17. Fatoyinbo, T.E.; Simard, M. Height and Biomass of Mangroves in Africa from ICESat/GLAS and SRTM. Int. J. Remote Sens. 2013, 34, 668-681. [CrossRef]

18. Narine, L.L.; Popescu, S.C.; Malambo, L. Using ICESat-2 to Estimate and Map Forest Aboveground Biomass: A First Example. Remote Sens. 2020, 12, 1824. [CrossRef]

19. Hu, T.; Zhang, Y.; Su, Y.; Zheng, Y.; Lin, G.; Guo, Q. Mapping the Global Mangrove Forest Aboveground Biomass Using Multisource Remote Sensing Data. Remote Sens. 2020, 12, 1690. [CrossRef]

20. Wulder, M.A.; White, J.C.; Nelson, R.F.; Næsset, E.; Ørka, H.O.; Coops, N.C.; Hilker, T.; Bater, C.W.; Gobakken, T. Lidar Sampling for Large-Area Forest Characterization: A Review. Remote Sens. Environ. 2012, 121, 196-209. [CrossRef]

21. Sidik, F.; Neil, D.; Lovelock, C.E. Effect of High Sedimentation Rates on Surface Sediment Dynamics and Mangrove Growth in the Porong River, Indonesia. Mar. Pollut. Bull. 2016, 107, 355-363. [CrossRef] [PubMed]

22. Mazzini, A.; Svensen, H.; Akhmanov, G.G.; Aloisi, G.; Planke, S.; Malthe-Sørenssen, A.; Istadi, B. Triggering and Dynamic Evolution of the LUSI Mud Volcano, Indonesia. Earth Planet. Sci. Lett. 2007, 261, 375-388. [CrossRef]

23. Karyadi, I.S. Aris Harnanto Pengaliran Lumpur Sidoarjo ke Laut Melalui Kali Porong; Bayumedia Publishing: Malang, Indonesia, 2012; ISBN 978-602-9136-89-0.

24. Jennerjahn, T.C.; Jänen, I.; Propp, C.; Adi, S.; Nugroho, S.P. Environmental Impact of Mud Volcano Inputs on the Anthropogenically Altered Porong River and Madura Strait Coastal Waters, Java, Indonesia. Estuar. Coast. Shelf Sci. 2013, 130, 152-160. [CrossRef]

25. Kure, S.; Winarta, B.; Takeda, Y.; Udo, K.; Umeda, M.; Mano, A.; Tanaka, H. Effects of Mud Flows from the LUSI Mud Volcano on the Porong River Estuary, Indonesia. J. Coast. Res. 2014, 70, 568-573. [CrossRef]

26. Sidik, F.; Hidayatullah, T.; Kadarisman, H.P.; Lovelock, C.E. Evaluation of Mangrove Development in a Created Mangrove Wetland in Porong, East Java. In Proceedings of the Regional Symposium on Mangrove Ecosystem Management in Southeast Asia, Surabaya, Indonesia, 27 February-1 March 2013; Ministry of Forestry Indonesia: Surabaya, Indonesia, March 2013.

27. Hamzah, F.; Widakti, N.; Sidik, F. The Growth of Mangroves in Created Wetland in the Porong River, East Java, Indonesia. J. Trop. Crop Sci. 2015, 2. [CrossRef]

28. Setiawan, A.; Realino, B.; Triyulianti, I.; Hamzah, F.; Murdimanto, A.; Putri, M.R.; Nugroho, D. Using WorldView-2 Imagery to Estimate Mangroves Density in the Porong Estuary. In Remote Sensing of the Asian Seas; Barale, V., Gade, M., Eds.; Springer International Publishing: Cham, Switzerland, 2019; pp. 377-393. ISBN 978-3-319-94065-6.

29. Badan Meteorologi dan Geofisika. Prakiraan Musim Hujan 2020/2021 di Indonesia; Badan Meteorologi dan Geofisika Republik Indonesia: Jakarta, Indonesia, 2020; Volume 1.

30. Aldrian, E.; Chen, C.-T.A.; Adi, S.; Prihartanto; Sudiana, N.; Nugroho, S.P. Spatial and Seasonal Dynamics of Riverine Carbon Fluxes of the Brantas Catchment in East Java. J. Geophys. Res. 2008, 113, G03029. [CrossRef]

31. Hoekstra, P. The development of two major Indonesian river deltas: Morphology and sedimentary aspects of the Solo and Porong delta, East Java. In Coastal Lowlands; Van der Linden, W.J.M., Cloetingh, S.A.P.L., Kaasschieter, J.P.K., Van de Graaff, W.J.E., Vandenberghe, J., Van der Gun, J.A.M., Eds.; Springer: Dordrecht, The Netherlands, 1989; pp. 143-159. ISBN 978-90-481-4038-1. 
32. Hoekstra, P. Hydrodynamics and depositional processes of the Solo and Porong Deltas, East Java, Indonesia. In Coastal Lowlands; Van der Linden, W.J.M., Cloetingh, S.A.P.L., Kaasschieter, J.P.K., Van de Graaff, W.J.E., Vandenberghe, J., Van der Gun, J.A.M., Eds.; Springer: Dordrecht, The Netherlands, 1989; pp. 161-173, ISBN 978-90-481-4038-1.

33. Lavigne, F. Rate of Sediment Yield Following Small-Scale Volcanic Eruptions: A Quantitative Assessment at the Merapi and Semeru Stratovolcanoes, Java, Indonesia. Earth Surf. Process. Landf. 2004, 29, 1045-1058. [CrossRef]

34. Jennerjahn, T.C.; Ittekkot, V.; Klöpper, S.; Adi, S.; Purwo Nugroho, S.; Sudiana, N.; Yusmal, A.; Prihartanto; Gaye-Haake, B. Biogeochemistry of a Tropical River Affected by Human Activities in Its Catchment: Brantas River Estuary and Coastal Waters of Madura Strait, Java, Indonesia. Estuar. Coast. Shelf Sci. 2004, 60, 503-514. [CrossRef]

35. Milliman, J.D.; Syvitski, J.P.M. Geomorphic/Tectonic Control of Sediment Discharge to the Ocean: The Importance of Small Mountainous Rivers. J. Geol. 1992, 100, 525-544. [CrossRef]

36. Mazzini, A. 10 Years of Lusi Eruption: Lessons Learned from Multidisciplinary Studies (LUSI LAB). Mar. Pet. Geol. 2018, 90, 1-9. [CrossRef]

37. The Jakarta Post Mangrove Forest to Be Developed at Porong River Mouth. Available online: https:/ /www.thejakartapost.com/ news / 2009/04/29/mangrove-forest-be-developed-porong-river-mouth.html (accessed on 19 November 2020).

38. Moloney, J.G.; Hilton, M.J.; Sirguey, P.; Simons-Smith, T. Coastal Dune Surveying Using a Low-Cost Remotely Piloted Aerial System (RPAS). J. Coast. Res. 2018, 345, 1244-1255. [CrossRef]

39. Casella, E.; Drechsel, J.; Winter, C.; Benninghoff, M.; Rovere, A. Accuracy of Sand Beach Topography Surveying by Drones and Photogrammetry. Geo-Mar. Lett. 2020, 40, 255-268. [CrossRef]

40. Mazzoleni, M.; Paron, P.; Reali, A.; Juizo, D.; Manane, J.; Brandimarte, L. Testing UAV-Derived Topography for Hydraulic Modelling in a Tropical Environment. Nat. Hazards 2020, 103, 139-163. [CrossRef]

41. Conlin, M.; Cohn, N.; Ruggiero, P. A Quantitative Comparison of Low-Cost Structure from Motion (SfM) Data Collection Platforms on Beaches and Dunes. J. Coast. Res. 2018, 34, 1341. [CrossRef]

42. Joyce, K.E.; Duce, S.; Leahy, S.M.; Leon, J.; Maier, S.W. Principles and Practice of Acquiring Drone-Based Image Data in Marine Environments. Mar. Freshw. Res. 2019, 70, 952-963. [CrossRef]

43. DJI Mavic Pro and Mavic Pro Platinum-Every Creative Moment-DJI. Available online: https://www.dji.com/nl/mavic (accessed on 16 November 2020).

44. DroneDeploy Documentation. Available online: https://support.dronedeploy.com/docs (accessed on 18 February 2021).

45. Zhu, X.; Hou, Y.; Weng, Q.; Chen, L. Integrating UAV Optical Imagery and LiDAR Data for Assessing the Spatial Relationship between Mangrove and Inundation across a Subtropical Estuarine Wetland. ISPRS J. Photogramm. Remote Sens. 2019, 149, 146-156. [CrossRef]

46. Zhang, W.; Qi, J.; Wan, P.; Wang, H.; Xie, D.; Wang, X.; Yan, G. An Easy-to-Use Airborne LiDAR Data Filtering Method Based on Cloth Simulation. Remote Sens. 2016, 8, 501. [CrossRef]

47. Roussel, J.-R.; Auty, D.; Coops, N.C.; Tompalski, P.; Goodbody, T.R.H.; Meador, A.S.; Bourdon, J.-F.; De Boissieu, F.; Achim, A. LidR: An R Package for Analysis of Airborne Laser Scanning (ALS) Data. Remote Sens. Environ. 2020, 251, 112061. [CrossRef]

48. Du, S.; Zhang, Y.; Qin, R.; Yang, Z.; Zou, Z.; Tang, Y.; Fan, C. Building Change Detection Using Old Aerial Images and New LiDAR Data. Remote Sens. 2016, 8, 1030. [CrossRef]

49. Widyaningrum, E.; Gorte, B.G.H. Comprehensive Comparison of Two Image-Based Point Clouds from Aerial Photos with Airborne LiDAR for Large-Scale Mapping. In Proceedings of the ISPRS-International Archives of the Photogrammetry, Remote Sensing and Spatial Information Sciences, Wuhan, China, 12 September 2017; Volume XLII-2/W7, pp. 557-565.

50. Martin Isenburg. LAStools. Available online: http://lastools.org/ (accessed on 23 November 2020).

51. Ayrey, E.; Fraver, S.; Kershaw, J.A.; Kenefic, L.S.; Hayes, D.; Weiskittel, A.R.; Roth, B.E. Layer Stacking: A Novel Algorithm for Individual Forest Tree Segmentation from LiDAR Point Clouds. Can. J. Remote Sens. 2017, 43, 16-27. [CrossRef]

52. Popescu, S.C.; Wynne, R.H.; Nelson, R.F. Estimating Plot-Level Tree Heights with Lidar: Local Filtering with a Canopy-Height Based Variable Window Size. Comput. Electron. Agric. 2002, 37, 71-95. [CrossRef]

53. Ministry of Marine Affairs and Fisheries Kajian Pemanfaatan Dan Pengembangan Muara Kali Porong Tahun 2010; Ministry of Marine Affairs and Fisheries: Jakarta, Indonesia, 2010.

54. Ministry of Marine Affairs and Fisheries Kajian Sebaran Lumpur Dan Perubahan Dasar Perairan Akibat Semburan Lumpur Sidoarjo Menggunakan Model Numerik; Ministry of Marine Affairs and Fisheries: Jakarta, Indonesia, 2009.

55. Federal Geographic Data Committee. National Standard for Spatial Data Accuracy; Geospatial Positioning Accuracy Standards; Federal Geographic Data Committee: Reston, VA, USA, 1998.

56. Pulighe, G.; Baiocchi, V.; Lupia, F. Horizontal Accuracy Assessment of Very High Resolution Google Earth Images in the City of Rome, Italy. Int. J. Digit. Earth 2016, 9, 342-362. [CrossRef]

57. Amani, M.; Ghorbanian, A.; Ahmadi, S.A.; Kakooei, M.; Moghimi, A.; Mirmazloumi, S.M.; Moghaddam, S.H.A.; Mahdavi, S.; Ghahremanloo, M.; Parsian, S.; et al. Google Earth Engine Cloud Computing Platform for Remote Sensing Big Data Applications: A Comprehensive Review. IEEE J. Sel. Top. Appl. Earth Obs. Remote Sens. 2020, 13, 5326-5350. [CrossRef]

58. Tamiminia, H.; Salehi, B.; Mahdianpari, M.; Quackenbush, L.; Adeli, S.; Brisco, B. Google Earth Engine for Geo-Big Data Applications: A Meta-Analysis and Systematic Review. ISPRS J. Photogramm. Remote Sens. 2020, 164, 152-170. [CrossRef]

59. Gorelick, N.; Hancher, M.; Dixon, M.; Ilyushchenko, S.; Thau, D.; Moore, R. Google Earth Engine: Planetary-Scale Geospatial Analysis for Everyone. Remote Sens. Environ. 2017, 202, 18-27. [CrossRef] 
60. Hansen, M.C.; Potapov, P.V.; Moore, R.; Hancher, M.; Turubanova, S.A.; Tyukavina, A.; Thau, D.; Stehman, S.V.; Goetz, S.J.; Loveland, T.R.; et al. High-Resolution Global Maps of 21st-Century Forest Cover Change. Science 2013, 342, 850. [CrossRef] [PubMed]

61. Donchyts, G.; Baart, F.; Winsemius, H.; Gorelick, N.; Kwadijk, J.; Van de Giesen, N. Earth's Surface Water Change over the Past 30 Years. Nat. Clim. Chang. 2016, 6, 810-813. [CrossRef]

62. Pekel, J.-F.; Cottam, A.; Gorelick, N.; Belward, A.S. High-Resolution Mapping of Global Surface Water and Its Long-Term Changes. Nature 2016, 540, 418-422. [CrossRef]

63. Luijendijk, A.; Hagenaars, G.; Ranasinghe, R.; Baart, F.; Donchyts, G.; Aarninkhof, S. The State of the World's Beaches. Sci. Rep. 2018, 8. [CrossRef]

64. Xiong, J.; Thenkabail, P.S.; Gumma, M.K.; Teluguntla, P.; Poehnelt, J.; Congalton, R.G.; Yadav, K.; Thau, D. Automated Cropland Mapping of Continental Africa Using Google Earth Engine Cloud Computing. ISPRS J. Photogramm. Remote Sens. 2017, 126, 225-244. [CrossRef]

65. $\mathrm{Wu}, \mathrm{Q}$. Geemap: A Python Package for Interactive Mapping with Google Earth Engine. J. Open Source Softw. $2020,5,2305$. [CrossRef]

66. User Guides-Sentinel-1 SAR-Overview-Sentinel Online. Available online: https://sentinel.esa.int/web/sentinel/user-guides / sentinel-1-sar/overview (accessed on 26 November 2020).

67. European Space Agency. Sentinel-1: ES's Radar Observatory Mission for GMES Operational Services; ESA Communications: Noordwijk, The Netherlands, 2012; ISBN 978-92-9221-418-0.

68. Sentinel-1 SAR GRD: C-Band Synthetic Aperture Radar Ground Range Detected, Log Scaling. Available online: https:// developers.google.com/earth-engine/datasets/catalog/COPERNICUS_S1_GRD (accessed on 26 November 2020).

69. User Guides-Sentinel-2 MSI-Overview-Sentinel Online. Available online: https://sentinel.esa.int/web/sentinel/user-guides/ sentinel-2-msi/overview (accessed on 26 November 2020).

70. European Space Agency. SENTINEL-2 User Handbook; ESA Standard Document; Issue 1 Rev 2.; European Space Agency: Paris, France, 2015.

71. USGS Landsat 7 Surface Reflectance Tier 1 I Earth Engine Data Catalog. Available online: https://developers.google.com/earthengine/datasets/catalog/LANDSAT_LE07_C01_T1_SR (accessed on 27 November 2020).

72. Masek, J.G.; Vermote, E.F.; Saleous, N.E.; Wolfe, R.; Hall, F.G.; Huemmrich, K.F.; Gao, F.; Kutler, J.; Lim, T.-K. A Landsat Surface Reflectance Dataset for North America, 1990-2000. IEEE Geosci. Remote Sens. Lett. 2006, 3, 68-72. [CrossRef]

73. USGS Landsat 8 Surface Reflectance Tier 1 I Earth Engine Data Catalog. Available online: https://developers.google.com/earthengine/datasets/catalog/LANDSAT_LC08_C01_T1_SR (accessed on 27 November 2020).

74. Vermote, E.; Justice, C.; Claverie, M.; Franch, B. Preliminary Analysis of the Performance of the Landsat 8/OLI Land Surface Reflectance Product. Remote Sens. Environ. 2016, 185, 46-56. [CrossRef]

75. Fassnacht, F.E.; Schiller, C.; Kattenborn, T.; Zhao, X.; Qu, J. A Landsat-Based Vegetation Trend Product of the Tibetan Plateau for the Time-Period 1990-2018. Sci. Data 2019, 6, 78. [CrossRef]

76. Ghorbanian, A.; Kakooei, M.; Amani, M.; Mahdavi, S.; Mohammadzadeh, A.; Hasanlou, M. Improved Land Cover Map of Iran Using Sentinel Imagery within Google Earth Engine and a Novel Automatic Workflow for Land Cover Classification Using Migrated Training Samples. ISPRS J. Photogramm. Remote Sens. 2020, 167, 276-288. [CrossRef]

77. Anchang, J.Y.; Prihodko, L.; Ji, W.; Kumar, S.S.; Ross, C.W.; Yu, Q.; Lind, B.; Sarr, M.A.; Diouf, A.A.; Hanan, N.P. Toward Operational Mapping of Woody Canopy Cover in Tropical Savannas Using Google Earth Engine. Front. Environ. Sci. 2020, 8, 4. [CrossRef]

78. Carrasco, L.; O'Neil, A.; Morton, R.; Rowland, C. Evaluating Combinations of Temporally Aggregated Sentinel-1, Sentinel-2 and Landsat 8 for Land Cover Mapping with Google Earth Engine. Remote Sens. 2019, 11, 288. [CrossRef]

79. Yuan, L.; Zhu, G.; Xu, C. Combining Synthetic Aperture Radar and Multispectral Images for Land Cover Classification: A Case Study of Beijing, China. J. Appl. Remote Sens. 2020, 14, 1. [CrossRef]

80. USGS. Landsat-A Global Land-Imaging Mission; Fact Sheet; USGS: Reston, VR, USA, 2013.

81. Mercier, A.; Betbeder, J.; Rumiano, F.; Baudry, J.; Gond, V.; Blanc, L.; Bourgoin, C.; Cornu, G.; Ciudad, C.; Marchamalo, M.; et al. Evaluation of Sentinel-1 and 2 Time Series for Land Cover Classification of Forest-Agriculture Mosaics in Temperate and Tropical Landscapes. Remote Sens. 2019, 11, 979. [CrossRef]

82. Otero, V.; Van De Kerchove, R.; Satyanarayana, B.; Mohd-Lokman, H.; Lucas, R.; Dahdouh-Guebas, F. An Analysis of the Early Regeneration of Mangrove Forests Using Landsat Time Series in the Matang Mangrove Forest Reserve, Peninsular Malaysia. Remote Sens. 2019, 11, 774. [CrossRef]

83. Tucker, C.J. Red and Photographic Infrared Linear Combinations for Monitoring Vegetation. Remote Sens. Environ. 1979, 8, 127-150. [CrossRef]

84. Huete, A.; Didan, K.; Miura, T.; Rodriguez, E.P.; Gao, X.; Ferreira, L.G. Overview of the Radiometric and Biophysical Performance of the MODIS Vegetation Indices. Remote Sens. Environ. 2002, 83, 195-213. [CrossRef]

85. Huete, A.R. A Soil-Adjusted Vegetation Index (SAVI). Remote Sens. Environ. 1988, 25, 295-309. [CrossRef]

86. Lee, J.S.; Jurkevich, L.; Dewaele, P.; Wambacq, P.; Oosterlinck, A. Speckle Filtering of Synthetic Aperture Radar Images: A Review. Remote Sens. Rev. 1994, 8, 313-340. [CrossRef] 
87. Amani, M.; Salehi, B.; Mahdavi, S.; Granger, J.E.; Brisco, B.; Hanson, A. Wetland Classification Using Multi-Source and MultiTemporal Optical Remote Sensing Data in Newfoundland and Labrador, Canada. Can. J. Remote Sens. 2017, 43, 360-373. [CrossRef]

88. Breiman, L. Random Forests. Mach. Learn. 2001, 45, 5-32. [CrossRef]

89. Rodriguez-Galiano, V.F.; Ghimire, B.; Rogan, J.; Chica-Olmo, M.; Rigol-Sanchez, J.P. An Assessment of the Effectiveness of a Random Forest Classifier for Land-Cover Classification. ISPRS J. Photogramm. Remote Sens. 2012, 67, 93-104. [CrossRef]

90. Mahdianpari, M.; Salehi, B.; Mohammadimanesh, F.; Homayouni, S.; Gill, E. The First Wetland Inventory Map of Newfoundland at a Spatial Resolution of $10 \mathrm{~m}$ Using Sentinel-1 and Sentinel-2 Data on the Google Earth Engine Cloud Computing Platform. Remote Sens. 2019, 11, 43. [CrossRef]

91. Belgiu, M.; Drăguţ, L. Random Forest in Remote Sensing: A Review of Applications and Future Directions. ISPRS J. Photogramm. Remote Sens. 2016, 114, 24-31. [CrossRef]

92. Jin, H.; Stehman, S.V.; Mountrakis, G. Assessing the Impact of Training Sample Selection on Accuracy of an Urban Classification: A Case Study in Denver, Colorado. Int. J. Remote Sens. 2014, 35, 2067-2081. [CrossRef]

93. Congalton, R.G.; Green, K. Assessing the Accuracy of Remotely Sensed Data Principles and Practices, Second Edition, 2nd ed.; CRC Press: Boca Raton, FL, USA, 2008; ISBN 978-0-429-14397-7.

94. Cochran, W.G. Sampling Techniques. In Wiley Series in Probability and Mathematical Statistics, 3rd ed.; Wiley: New York, NY, USA, 1977; ISBN 978-0-471-16240-7.

95. Topouzelis, K.; Psyllos, A. Oil Spill Feature Selection and Classification Using Decision Tree Forest on SAR Image Data. ISPRS J. Photogramm. Remote Sens. 2012, 68, 135-143. [CrossRef]

96. Guan, H.; Li, J.; Chapman, M.; Deng, F.; Ji, Z.; Yang, X. Integration of Orthoimagery and Lidar Data for Object-Based Urban Thematic Mapping Using Random Forests. Int. J. Remote Sens. 2013, 34, 5166-5186. [CrossRef]

97. Du, P.; Samat, A.; Waske, B.; Liu, S.; Li, Z. Random Forest and Rotation Forest for Fully Polarized SAR Image Classification Using Polarimetric and Spatial Features. ISPRS J. Photogramm. Remote Sens. 2015, 105, 38-53. [CrossRef]

98. Patel, N.; Kaushal, B. Improvement of User's Accuracy through Classification of Principal Component Images and Stacked Temporal Images. Geo-Spat. Inf. Sci. 2010, 13, 243-248. [CrossRef]

99. Pusat Pemanfaatan Penginderaan Jauh LAPAN Peta Sebaran Hutan Mangrove Di Indonesia. Available online: http:/ /103.31.159 $.29 / \mathrm{maps} / 624$ (accessed on 11 January 2021).

100. Nardin, W.; Vona, I.; Fagherazzi, S. Sediment Deposition Affects Mangrove Forests in the Mekong Delta, Vietnam. Cont. Shelf Res. 2021, 213, 104319. [CrossRef]

101. McKee, K.L.; Mendelssohn, I.A. Root Metabolism in the Black Mangrove (Avicennia Germinans (L.) (L): Response to Hypoxia. Environ. Exp. Bot. 1987, 27, 147-156. [CrossRef]

102. Krauss, K.W.; Keeland, B.D.; Allen, J.A.; Ewel, K.C.; Johnson, D.J. Effects of Season, Rainfall, and Hydrogeomorphic Setting on Mangrove Tree Growth in Micronesia. Biotropica 2007, 39, 161-170. [CrossRef]

103. Lymburner, L.; Bunting, P.; Lucas, R.; Scarth, P.; Alam, I.; Phillips, C.; Ticehurst, C.; Held, A. Mapping the Multi-Decadal Mangrove Dynamics of the Australian Coastline. Remote Sens. Environ. 2020, 238, 111185. [CrossRef]

104. Chen, B.; Xiao, X.; Li, X.; Pan, L.; Doughty, R.; Ma, J.; Dong, J.; Qin, Y.; Zhao, B.; Wu, Z.; et al. A Mangrove Forest Map of China in 2015: Analysis of Time Series Landsat 7/8 and Sentinel-1A Imagery in Google Earth Engine Cloud Computing Platform. ISPRS J. Photogramm. Remote Sens. 2017, 131, 104-120. [CrossRef] 